\title{
Influence of Historical Land-Use Change on Contemporary Channel Processes, Form, and Restoration
}

\author{
Jerry R. Miller ${ }^{1, *}$, David Grow ${ }^{2}$ and L. Scott Philyaw ${ }^{3}$ \\ 1 Department of Geosciences \& Natural Resources, Western Carolina University, Cullowhee, NC 28723, USA \\ 2 Independent Researcher, P.O. Box 215, English, IN 47118, USA; davegrow@coopsone.com \\ 3 Department of History, Western Carolina University, Cullowhee, NC 28723, USA; philyaw@wcu.edu \\ * Correspondence: jmiller@wcu.edu; Tel.: +1-828-227-2269
}

Citation: Miller, J.R.; Grow, D.;

Philyaw, L.S. Influence of Historical

Land-Use Change on Contemporary

Channel Processes, Form, and

Restoration. Geosciences 2021, 11, 423.

https://doi.org/10.3390/geosciences 11100423

Academic Editors: Luca Mao and Jesus Martinez-Frias

Received: 21 August 2021

Accepted: 10 October 2021

Published: 15 October 2021

Publisher's Note: MDPI stays neutral with regard to jurisdictional claims in published maps and institutional affiliations.

Copyright: (C) 2021 by the authors Licensee MDPI, Basel, Switzerland. This article is an open access article distributed under the terms and conditions of the Creative Commons Attribution (CC BY) license (https:// creativecommons.org/licenses/by/ $4.0 /)$.

\begin{abstract}
Big Harris Creek, North Carolina, possesses a geomorphic history similar to many drainages in the southern Appalachian piedmont, and was used herein as a representative example of the influence of European settlement on contemporary channel form and processes. The integrated use of historical, dendrogeomorphic, stratigraphic, and cartographic data shows that the conversion of land-cover from a mix of natural conditions and small farms to commercial cotton production in the late 1800s and early 1900s led to significant upland soil erosion, gully formation, and the deposition of legacy sediments on the valley floor. Aggradation was followed by catchment-wide channel incision in the mid-1900s in response to reforestation and the implementation of soil conservation measures. Collectively, the responses form an aggradational-degradational episode (ADE) that produced the geomorphic framework for the contemporary processes operating along the drainage network. Defined, characterized, and mapped process zones (stream reaches of similar form and process) show that the type, intensity, and evolutionary sequence of geomorphic responses varied within the catchment as a function of the position along the drainage network, the erosional resistance of the underlying bedrock, and the valley characteristics (particularly width). Understanding the spatially variable influences of the ADE on contemporary, reach-scale geomorphic processes provides valuable insights for restoration as it helps inform practitioners of the sensitivity and ways in which the reach is likely to respond to future disturbances, the potential impacts of processes on proposed manipulations intended to achieve the project's restoration goals, and the potential risk(s) involved with channel reconstruction. The latter is strongly controlled by geotechnical differences between erosionally resistant precolonial deposits and easily eroded legacy sediments that locally form the channel banks following the ADE.
\end{abstract}

Keywords: river restoration; channel evolution; legacy sediments; geomorphic responses; European settlement

\section{Introduction}

Recent geomorphic and alluvial stratigraphic studies have demonstrated that, in most environments, humans currently represent the primary driver of geomorphic change, the rates of which are generally orders of magnitude greater than those associated with natural geomorphic processes [1-4]. Kemp et al. [4], for example, found by analyzing more than 4000 documented rates of sediment accumulation that alluvial deposition in North America was roughly stable for the past 40,000 years before increasing by about 10 -fold in response to the anthropogenic disturbances associated with European settlement. The dramatic transition in geomorphic processes following European settlement is widely recognized by the occurrence of dark, organic-rich precolonial deposits that are abruptly overlain by historic sediments [1,5-14]. In fact, the occurrence of these historical, anthropogenically derived deposits is so pervasive that they are now referred to as post-settlement deposits or, more commonly, legacy sediments (see James [15] for a detailed review of their definition). 
The deposition of legacy sediments has largely been attributed to land-use/land-cover changes associated with agriculture (e.g., $[5-9,14])$ and/or the influx of tailings materials to river valleys from mining operations ([8,16-19]). The impacts of agriculture are particularly prevalent in North America, where legacy deposits have been recognized throughout the eastern piedmont and the Mississippi River valley, among other locations. The nature and rates of the geomorphic responses to these agricultural disturbances have varied between catchments, in part because of differences in the intensity of the anthropogenic impacts and the inherent geomorphic sensitivity of the landscape [20]. Nonetheless, the general nature of the documented disturbance-response system was often characterized by an aggradational-degradational episode (ADE) that includes the following: (1) the extensive clearing of hillslope and valley bottoms, resulting in major changes in landcover; (2) hillslope gullying and accelerated soil erosion resulting in increased sediment loads to the channel; (3) enhanced rates of deposition on floodplains and/or upon the channel bed, producing a thick sequence of highly stratified legacy sediments; and (4) a period of renewed land-use/land-cover change, such as reforestation, accompanied by the application of soil conservation practices that reduced sediment production and resulted in channel incision.

Recent studies have shown that such ADEs not only represent an interesting topic of academic analysis, but are of importance to river restoration and contemporary water quality conditions, among a host of other areas of resource management [15]. For example, it is now widely accepted that contemporary sediment loads (and water quality in general) can be significantly influenced by the influx of legacy sediments (and their associated contaminants) to the channel system [21-25]. What is less widely recognized is how historical geomorphic events, and the stratigraphic deposits produced, can impact contemporary channel processes, form, and restoration $[20,26,27]$.

The primary goal of this paper is to explore the influence of the ADE associated with European settlement in the southeastern United States on contemporary channel form and processes with respect to river restoration. River restoration has utilized a wide spectrum of modifications to river channels, floodplains, and/or water, sediment, and chemical regimes to improve degraded watersheds [28]. The goal of restoration is not always to improve ecological functions $[28,29]$. Herein, however, our primarily concern is with ecological river restoration, which can be defined as the process of assisting river systems to recover from a degraded state by re-establishing the hydrologic, geomorphic, and ecological processes needed to support a natural ecosystem (after [28,30,31]. Defined as such, the primary goal of ecological restoration is to develop a self-sustaining and dynamic system to the degree possible given the regional environmental framework [32-36].

The objective of this study was carried out using the Big Harris Creek restoration project in North Carolina as a representative example (Figure 1). This restoration project is one of the largest and most expensive restoration efforts in North Carolina, and includes the upper $9.6 \mathrm{~km}^{2}$ of Big Harris Creek located within the piedmont physiographic province of Cleveland County, North Carolina near the town of Polkville (Figure 1). As will be shown, the Big Harris Creek Basin exhibits a geomorphic history similar to many rural, headwater catchments in the eastern United States that were impacted by European settlement and characterized by legacy sediments that did not accumulate upstream of mill ponds. Thus, the results obtained from Big Harris Creek are likely to be applicable to a wide range of other catchments. 


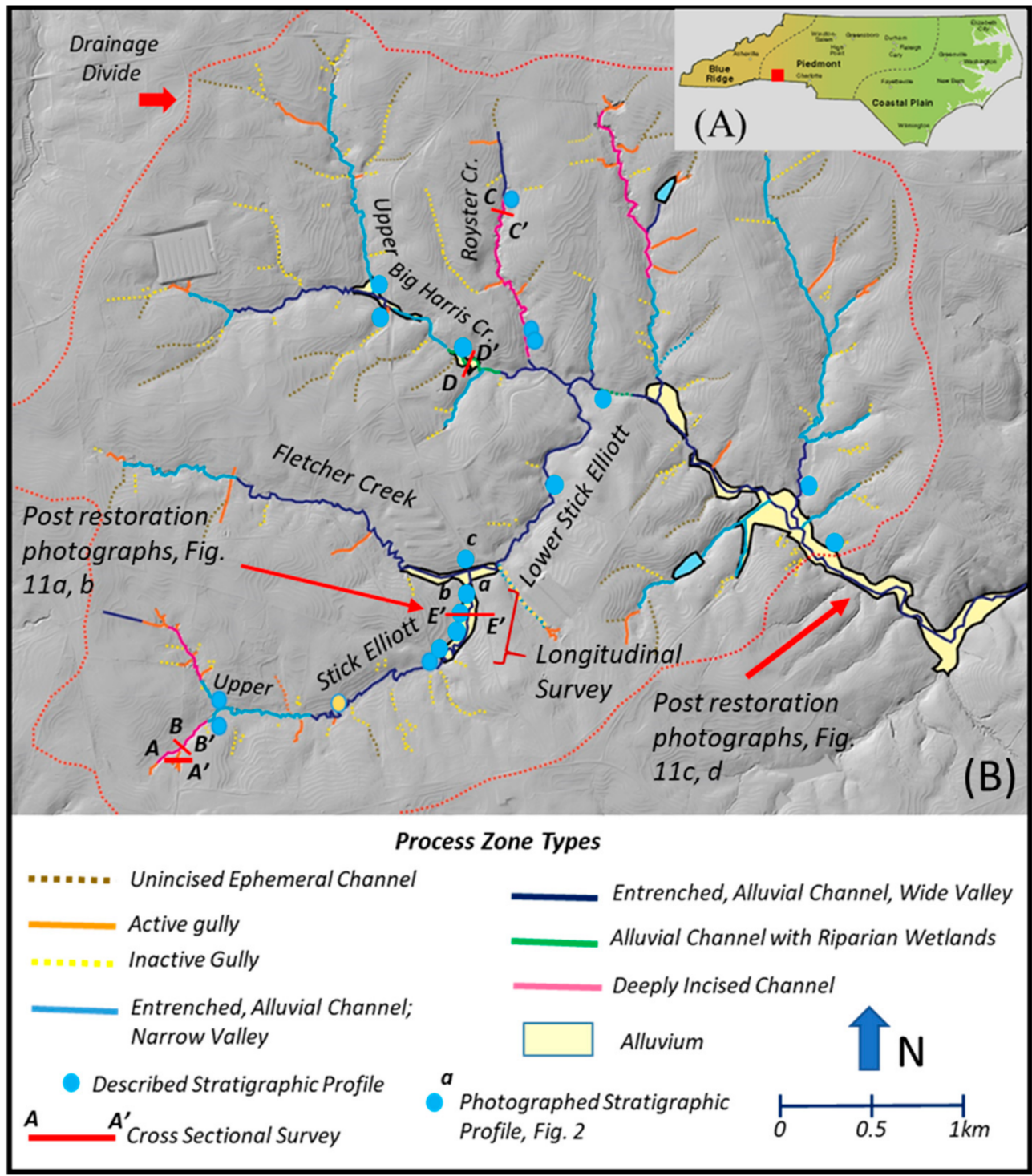

Figure 1. (A) Map showing the location of the Big Harris Creek basin in North Carolina; (B) Spatial distribution of the seven defined process zones within the basin and the location of the described stratigraphic sections. Mapped areas of alluvium characterized by legacy sediments overlying precolonial deposits. North Carolina map from the USGS. LiDAR DEM from the North Carolina Spatial Data Download Center (https:/ / sdd.nc.gov/, accessed on 10 October 2021). See Table 1 for process zone characteristics. Figure S1 and Table S1 provide the location and descriptions of specific stratigraphic sections. 
Table 1. Summary of process zone types and characteristics. See Figure 1 for spatial distribution of process zones.

\begin{tabular}{|c|c|c|c|}
\hline Reach & $\begin{array}{c}\text { Valley } \\
\text { Characteristics }\end{array}$ & Slope & Description \\
\hline $\begin{array}{l}\text { Unincised Ephemeral } \\
\text { Channel }\end{array}$ & $\begin{array}{l}\text { Concaved depression } \\
\text { lacking a defined } \\
\text { channel }\end{array}$ & $\begin{array}{l}\text { Relatively high } \\
\qquad(\sim 0.02)\end{array}$ & $\begin{array}{c}\text { Concaved depression that grades downstream to } \\
\text { active or inactive gully, or perennial channel. } \\
\text { Floor of depression generally composed of } \\
\text { upland or colluvial soils. }\end{array}$ \\
\hline Active Gully & $\begin{array}{l}\text { Relatively steep, } \\
\text { concaved depression } \\
\text { without alluvial } \\
\text { sediments }\end{array}$ & $\begin{array}{l}\text { Relatively high } \\
\qquad(\sim 0.02+)\end{array}$ & $\begin{array}{l}\text { Low-order, trench (generally }>2.5 \mathrm{~m} \text { ) cut in } \\
\text { colluvial or upland sediments; often found at } \\
\text { upstream most section of the drainage network; } \\
\text { occasionally occur as trench cut into hillslope; } \\
\text { gully often terminates in amphitheater shaped } \\
\text { headcut; reach dominated by ongoing incision, } \\
\text { headcut migration, and/or bank erosion; no } \\
\text { legacy sediments present; limited sediment } \\
\text { storage or other channel features }\end{array}$ \\
\hline Inactive Gully & $\begin{array}{l}\text { Hillslope or concaved } \\
\text { depression without } \\
\text { alluvial sediments }\end{array}$ & $\begin{array}{l}\text { Relatively high } \\
\qquad(\sim 0.02)\end{array}$ & $\begin{array}{l}\text { Low-order, trench cut in colluvial or upland } \\
\text { sediments that have been re-vegetated; bottom } \\
\text { of trench exhibits limited erosion or sediment } \\
\text { transport. Occasionally terminates upstream in } \\
\text { amphitheater shaped headcut with no recent } \\
\text { signs of erosion. Some local storage of colluvial } \\
\text { sediment. }\end{array}$ \\
\hline $\begin{array}{l}\text { Entrenched Alluvial } \\
\text { Channel with Narrow } \\
\text { Valley }\end{array}$ & $\begin{array}{l}\text { Narrow, well-defined } \\
\text { alluvial valley floor }\end{array}$ & $\begin{array}{l}\text { Moderate to low } \\
\quad(\sim 0.01-0.015)\end{array}$ & $\begin{array}{c}\text { Channel entrenched } 1-3 \text { m below narrow valley } \\
\text { floor that possesses limited alluvial sediments; } \\
\text { may possess an inset terrace within the trench; } \\
\text { banks are often semi-vertical and composed of } \\
\text { both pre- and post-settlement (legacy) deposits } \\
\text { as well as upland sediments; reach dominated by } \\
\text { bank erosion and minor channel incision; local } \\
\text { occurrences of bedrock on channel floor. } \\
\text { Sediment storage occurs in the channel bed, the } \\
\text { inset terrace when present, and on the valley } \\
\text { floor. }\end{array}$ \\
\hline $\begin{array}{l}\text { Entrenched Alluvial } \\
\text { Channel with Wide } \\
\text { Valley }\end{array}$ & $\begin{array}{l}\text { Wide, well-defined } \\
\text { alluvial valley floor }\end{array}$ & $\begin{array}{l}\text { Moderate to low } \\
\quad(\sim 0.01-0.015)\end{array}$ & $\begin{array}{l}\text { Channel entrenched } 1 \text { to }>4 \text { m below valley floor; } \\
\text { channel bed prone to large changes during } \\
\text { floods, but composed of well-defined } \\
\text { morphologic units; banks are typically vertical, } \\
\text { and subject to significant erosion by corrasion } \\
\text { and with frequent slab failures; in-channel } \\
\text { storage is high in bars and on the valley floor; } \\
\text { bank materials dominated by both legacy and } \\
\text { pre-settlement; local bedrock exposures. }\end{array}$ \\
\hline $\begin{array}{l}\text { Alluvial Channel with } \\
\text { Riparian Wetlands }\end{array}$ & Wide, alluvial valley & $\begin{array}{l}\text { Moderate to low } \\
\quad(\sim 0.01-0.015)\end{array}$ & $\begin{array}{l}\text { Channel entrenchment is limited and cut into } \\
\text { alluvial fill; riparian wetlands with small springs } \\
\text { border channel; bedrock close to surface, and } \\
\text { locally outcrops in bed and banks; reaches are } \\
\text { currently stable; moderate sediment storage in } \\
\text { channel bars and on floodplain/valley floor. }\end{array}$ \\
\hline $\begin{array}{l}\text { Deeply Incised } \\
\text { Channel }\end{array}$ & $\begin{array}{l}\text { Variable valley width } \\
\text { composed of both } \\
\text { colluvial and alluvial } \\
\text { sediments }\end{array}$ & $\begin{array}{l}\text { High to moderate } \\
\qquad(\sim 0.15-0.2)\end{array}$ & $\begin{array}{l}\text { Channel entrenched } 4-5 \text { m below valley floor; } \\
\text { trench walls, composed of relatively old alluvial } \\
\text { deposits and saprolite; confined flow allows for } \\
\text { efficient sediment transport; erosion of steep } \\
\text { trench walls is significant; post-settlement } \\
\text { deposits limited to local terraces inset in trench, } \\
\text { particularly along downstream reaches. }\end{array}$ \\
\hline
\end{tabular}




\section{Materials and Methods}

A combination of historical, geomorphic, alluvial stratigraphic, topographic, and dendrogeomorphic data was used to document the late Holocene (approximately the past 4000 years) geomorphic history of the watershed. Included in this analysis was the delineation, characterization, and mapping of process zones, which were used to capture the spatial variations in channel and valley morphology, landforms, and processes within a catchment. Process zones were defined as segments of the drainage network that possess similar morphological and process characteristics (Figure 1). For this study, maps originally created by Miller et al. [25] using aerial photography were revised using $1 \mathrm{~m}$ resolution LiDAR DEMs obtained from the North Carolina Spatial Download Center. The revision allowed the process zones to more closely align with variations in landscape sensitivity and channel and valley morphologic characteristics of importance to restoration design. The revised process zones were defined on the basis of valley width, the depth of channel incision, the occurrence and extent of alluvial valley fill, the presence of bedrock outcrops along the channel floor, and the existence of amphitheater-shaped headcuts at the upstream end of gullies (Figure 1). Once mapped on the LiDAR DEMs, the processes zones were verified in the field where access was possible (access was inhibited by some landowners). The field observations showed that a few short reaches ( $\sim 50$ to $75 \mathrm{~m}$ ) of one process zone could be embedded with a different process zone mapped on the LiDAR DEMs. Thus, the longitudinal resolution of the process zones shown on Figure 1 is about $75 \mathrm{~m}$. An unfortunate consequence of the resolution of our mapping scheme is that short $(<5 \mathrm{~m})$ reaches of exposed bedrock could not be defined and mapped throughout the drainage network.

The alluvial and colluvial stratigraphy of the valley fill was described in bank exposures at 22 locations within the basin (Figure 1). Delineation and characterization of the stratigraphic units and facies focused on parameters that previous studies had found were useful for the delineation of legacy and precolonial deposits, including (1) color, (2) organic matter content, (3) grain size (texture), (4) stratification, and (5) degree of weathering. The vertical character of the units was described along a narrow $(<50 \mathrm{~cm})$ profile that extended from the ground surface to the channel bed. The general stratigraphic and sedimentologic nature of the alluvial materials was defined following the procedures outlined in Kottlowski [37] and Bridge [38], whereas the detailed descriptions in Supplemental Materials (Table S1) were based on the nomenclature outlined in the U.S. Soil Survey Manual [39]. The relative age of the deposits was defined on the basis of artifacts buried within the deposits, the degree of sediment weathering (e.g., buried soils), and the use of dendrochronologic methods. The numeric (absolute) age of the precolonial deposits was also verified by radiocarbon dating of organic materials. Three radiocarbon analyses were performed by International Chemical Inc., Sunrise, FL, USA.

Dendrochronological methods were used to determine (1) the approximate timing of valley floor and terrace stabilization and (2) the rates of bank erosion. Thirty-two tulip poplar trees (genus-Liriodendron) were cored along Upper Big Harris, Upper Stick Elliott, and Royster creeks as well as several tributaries (Figure S2) using a Swedish increment borer. Two cores were taken from each tree at approximately $1 \mathrm{~m}$ above the ground. At this height, the inner dates provide a minimum age for the surface. Generally, two to five years can be added to each inner date to estimate tree germination on the surfaces. For this study, the inner dates were used as the best estimate for dating and grouping of the data for analysis, and ages were defined as years before 2017. Following core collection, the cores were mounted, prepared, and cross-dated at Western Carolina University using skeleton plots according to procedures described by Stokes and Smiley [40]. Decadal-scale, bank erosion rates were determined by measuring the amount of erosion that had occurred around the roots of dendrochronologically dated trees growing along the upper edge of the channel banks (patterned after Hupp and Bornette, [40]). More specifically, bank erosion rates were estimated for 17 trees by dividing the amount of erosion by the determined age of the tree, where the amount of erosion was defined as the distance from the channel bank 
to the most distant root exposed within the channel (Figure S3). The amount of measured erosion is a minimum of that which could have occurred at the site. Thus, the method provides a conservative (minimum) estimate of erosion rates.

Longitudinal and cross-channel surveys were conducted at representative sites along the major process zone types to characterize (1) the dimensions and form of the channel and other landforms (e.g., the floodplain and terraces) within the reach, and (2) the topographic relationships between landforms and stratigraphic units with the reach (Figure 1). All surveys were conducted using a Leica Total Station accurate to $<1 \mathrm{~cm}$.

A total of 198 sediment samples were collected at approximately $5 \mathrm{~cm}$ intervals from the ground surface to the base of five stratigraphic sections that possessed both legacy sediments and precolonial deposits. Sample intervals did not cross horizon (or layer) boundaries. The sampled stratigraphic sections included USE-1 through USE-4, and BHT-3 (Figure S1). These sites were selected because they are the focus of an associated geochemical fingerprinting study aimed at quantitatively determining the source of the legacy sediments. The grain-size distribution of the $<2 \mathrm{~mm}$ size fraction was determined at 0.5 phi intervals using a Mastersizer 2000 particle size analyzer (Malvern Instruments, Malvern, UK). Prior to analysis, $\sim 5 \mathrm{~g}$ of sediment was combined in a $50 \mathrm{~mL}$ beaker with $5 \mathrm{~mL}$ of pyrophosphate and $\sim 30$ to $40 \mathrm{~mL}$ of deionized water. The mixture was stirred and left to sit overnight to aid in particle dispersal. Herein, we use the percent of silt and clay $(<63 \mu \mathrm{m})$ in the deposits as a simple descriptor of sediment texture because this size fraction strongly influences the cohesion and erodibility of the bank materials. The texture of the $<2 \mathrm{~mm}$ sediment and the presence of gravel sediments were also described in the field. If present, the intermediate diameter of 5 to 10 gravel clasts was measured using a tape measure.

An historical assessment of land-use change in the basin and surrounding region was also conducted by identifying, obtaining, and reviewing historical documents and aerial photographs pertinent to the area as well as by interviewing local landowners and staff from local land management agencies.

\section{Study Area: Geomorphic and Geographic Setting}

Land-use/land-cover in April 2018 within the Big Harris Creek project area was dominated by forest $(\sim 48 \%)$ and grassed/pastured areas $(\sim 44 \%)$. The remainder of the land-use/land-cover types include homes, turkey farming facilities, roads, and row crops. Prior to restoration in 2017 and 2018, the axial channel of Big Harris Creek and its major tributaries was similar to many headwater drainage systems in the piedmont of the southeastern United States; they were incised by approximately 1.5 to more than $5 \mathrm{~m}$ below the valley floor, and the channel was considered by the local restoration community to be hydrologically disconnected from its "floodplain". Moreover, the influx of sediments and nutrients, derived in large part from bank erosion, were major issues. The implemented project was intended, in part, to (1) reduce the rates of bank erosion to improve water quality (particularly with regards to suspended sediments), (2) hydrologically reconnect selected channel reaches with its floodplain, and (3) improve upon overall ecological health of the channel and riparian ecosystems. The implemented project utilized a wide range of approaches, including the complete reconfiguration and/or reconstruction of channel reaches (including the creation of a channel in a new location on the valley floor), the local use of instream rock and wood structures, the implementation of various forms of bank treatments, and the revegetation of the riparian zone.

\section{Results and Discussion}

\subsection{Geomorphic Responses to Land-Use Change}

Historical records were combined with stratigraphic, topographic, and dendrogeomorphic data to assess the geomorphic responses of the Big Harris Creek basin during and since European settlement. The recent geomorphic history of Big Harris Creek roughly corresponds to other drainages that possess legacy sediments that were not associated 
with mill ponds in the midwestern and eastern United States [5-7,9,14]. Dark colored, organic-rich alluvial sediments are located along the base of the channel banks of midand downstream segments of the drainage network (Figure 2A,B). Within some drainages (e.g., Upper Stick Elliott Creek, Figure 1), they could be continuously traced along the channel for more than $400 \mathrm{~m}$ (Figure 3F). These sediments were interpreted to represent precolonial floodplain deposits on the basis of (1) radiocarbon dates obtained on samples of organic materials collected from within the deposits or along its upper surface that range between 290 + / - 30 YBP and 3760 + / - 30 YBP (Table S3); (2) the occurrence of local buried soils, particularly at the surface of the deposits; and (3) their lack of historic artifacts. The upper $0.5-2 \mathrm{~m}$ of these precolonial deposits was dominated by weathered, non-stratified, organic-rich, loamy materials (Table S1), interpreted as a buried A-horizon, suggesting the floodplain surface was generally stable and characterized by relatively slow rates of deposition. The dark-colored, cohesive sediments grade downward into grey (mottled) fine-grained, silt to loamy sands that subsequently transition near the base of the banks into coarse sands and gravels (Table S1). Clasts within the gravel deposits are often encompassed by a fine-grained loamy to loamy sand matrix. Collectively, the sediments form a fining-upward sequence commonly associated with the alluvial floodplain architecture of single-thread, meandering channels.

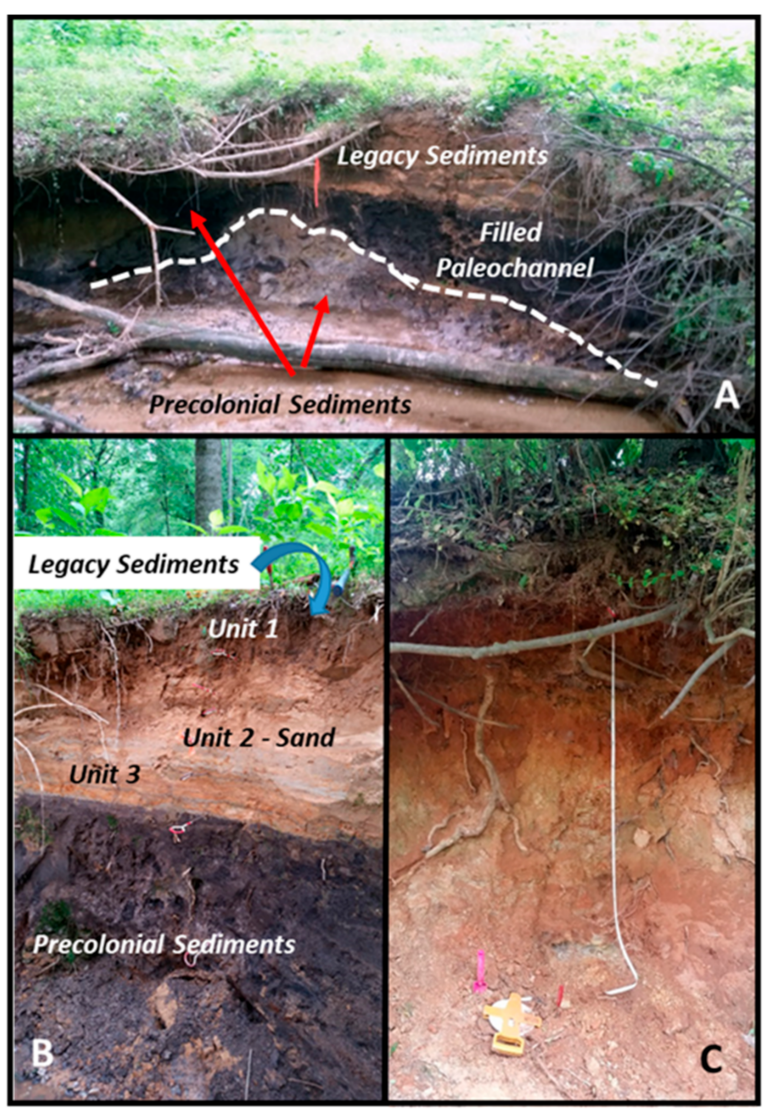

Figure 2. Bank exposure located along an entrenched alluvial channel (A) near the confluence of Stick Elliot and Fletcher Creek, and (B) upstream, along Stick Elliot Creek. Reddish brown to buffcolored sediments in photos A and B represent stratified legacy deposits that locally contain loose, sand-sized sediments. Dark, organic-rich sediments are interpreted as cohesive, erosionally resistant precolonial deposits; (C) highly weathered alluvial sediments and soil that underlie upland areas (hillslopes) near the confluence of Stick Elliott and Fletcher Creeks. See Figure 1 and Figure 5 for stream channel locations. 

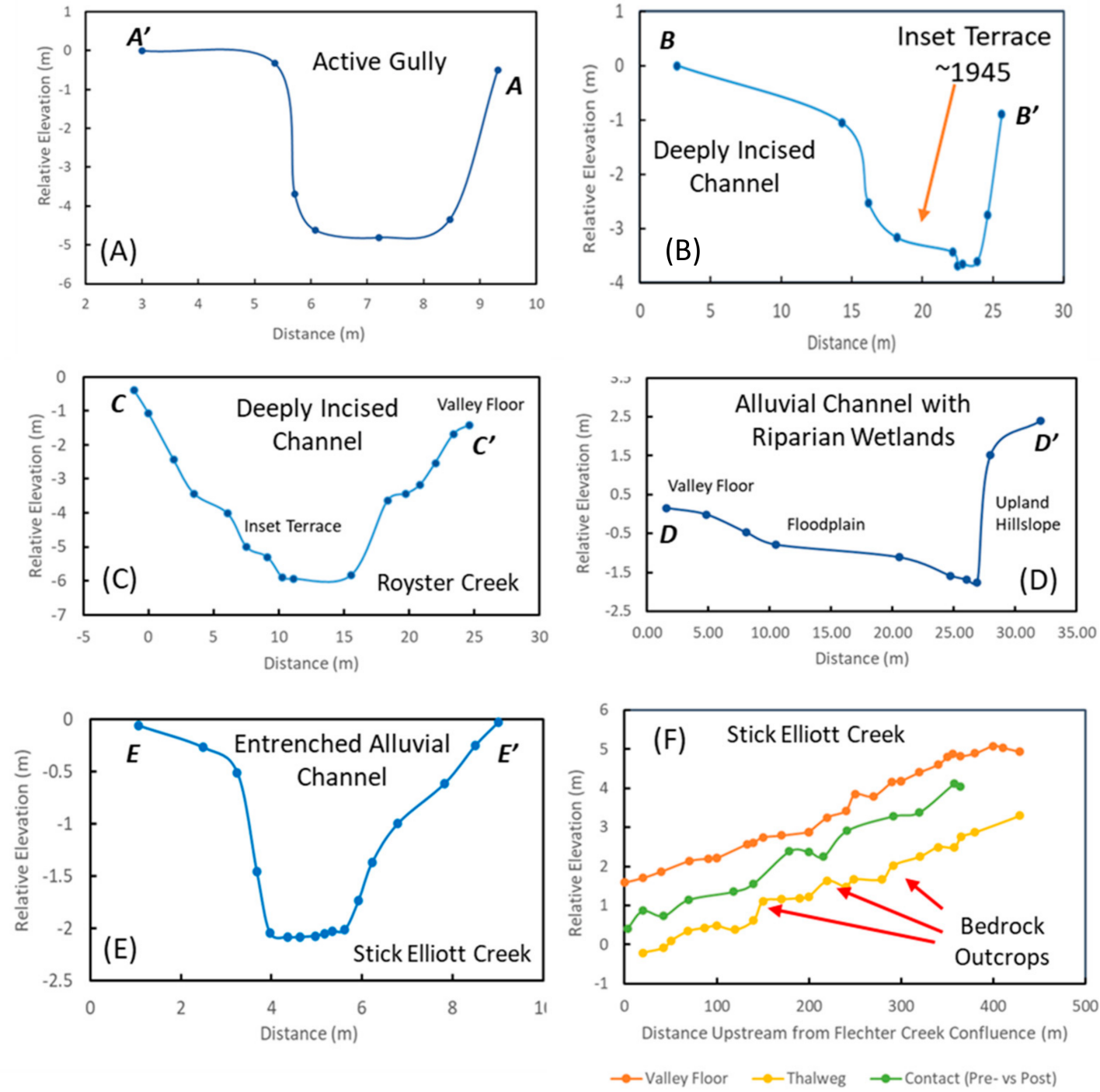

Figure 3. Representative topographic surveys across the major process zones defined within the project area, including (A) an active gully at the headwaters of Stick Elliott Creek, (B,C) deeply incised channels, (D) an alluvial channel with riparian wetlands located along the axial channel of Big Harris Creek, and (E) an entrenched alluvial channel along Stick Elliott Creek; (F) a longitudinal profile along the lower reach of Stick Elliott Creek shows the relationship between the contemporary channel bed (thalweg)(yellow line), the valley floor (orange line), and the contact between the legacy and precolonial deposits (green line). See Figure 1 for survey locations.

Immigration to the area of Big Harris Creek began during the mid-1700s. Most settlers practiced general farming with an emphasis on self-sufficiency while also producing some crops and other goods for market. Dispersed populations and extensive land-use practices characterized the region until the Civil War (1861-1865). A typical antebellum farm included a mix of free-range livestock (usually pigs), vegetable gardens, a few orchard trees, and corn fields for their own consumption and as a commodity. Woodlands provided fuel, building materials, and wild game. Fields that had lost their fertility were sometimes allowed to revert to woodland. The result was not a natural conditions, but a landscape that was only lightly and intermittently impacted by settlers without any large-scale clearing of the landscape [41].

The southeastern United States is historically known for its cotton plantations, but very little cotton was grown in Cleveland County, the location of Big Harris Creek, until after the Civil War ( 1865) when the enthusiasm for commercial cotton production grew [42]. By World War I, Cleveland County was one of North Carolina's most productive cotton- 
growing regions. Cotton, as a row crop, required whole-scale clearing of both upland and lowland areas, enhancing the likelihood of runoff to erode surface soils. Trimble [7] suggests that about 10 to $12.7 \mathrm{~cm}$ of topsoil was eroded from upland areas in the region of Big Harris Creek. Other estimates suggest the losses of topsoil were even higher, ranging between 15 and $20 \mathrm{~cm} \mathrm{[43].} \mathrm{In} \mathrm{addition} \mathrm{to} \mathrm{the} \mathrm{widespread} \mathrm{removal} \mathrm{of} \mathrm{topsoils} \mathrm{by} \mathrm{sheet} \mathrm{and}$ rill erosion, gullies formed on hillslopes and within zero-order drainages, particularly in response to tropical storms and hurricanes that tracked across the region (e.g., in 1916). As occurred in other parts of the piedmont [6,14], the enhanced sediment loads led to the relatively rapid deposition of legacy sediment on floodplains and within the channel bed (Figure 2A,B).

The legacy deposits abruptly overlie the precolonial deposits and are characterized by highly stratified, dark reddish brown to buff-colored sediments that contain historic artifacts (e.g., metal straps), indicating that the unit post-dates European settlement. At many sites, the legacy deposits can be subdivided into three distinct units of varying grain size and cohesion ranging from cohesive loams to loose sand (Figure 4). The uppermost unit (ranging from about 10 to $35 \mathrm{~cm}$ in thickness) is typically dominated by massive (non-stratified), dark brown to reddish brown sandy loams (Table S1). The grain size distribution of these materials is relatively uniform (Figure 4). This upper unit frequently overlies stratified and/or laminated sands or loamy sands of variable thickness. Locally, particularly along Stick Elliott Creek (Figure 2B), laterally discontinuous lenses of wellsorted, loose sand that exceeded $30-40 \mathrm{~cm}$ in thickness occurred for a few meters to tens of meters along the channel. At other sites, loose, well-sorted layers of sand were interbedded with darker, loamy sands. This intermediate unit overlies dark brown loam to loamy sands interbedded with darker colored loamy sediments that measure from 5 to $10 \mathrm{~cm}$ in thickness [25]. The finer-grained loamy sediments often contain significant amounts of organic matter that was presumably derived from the underlying precolonial deposits (Table S1).

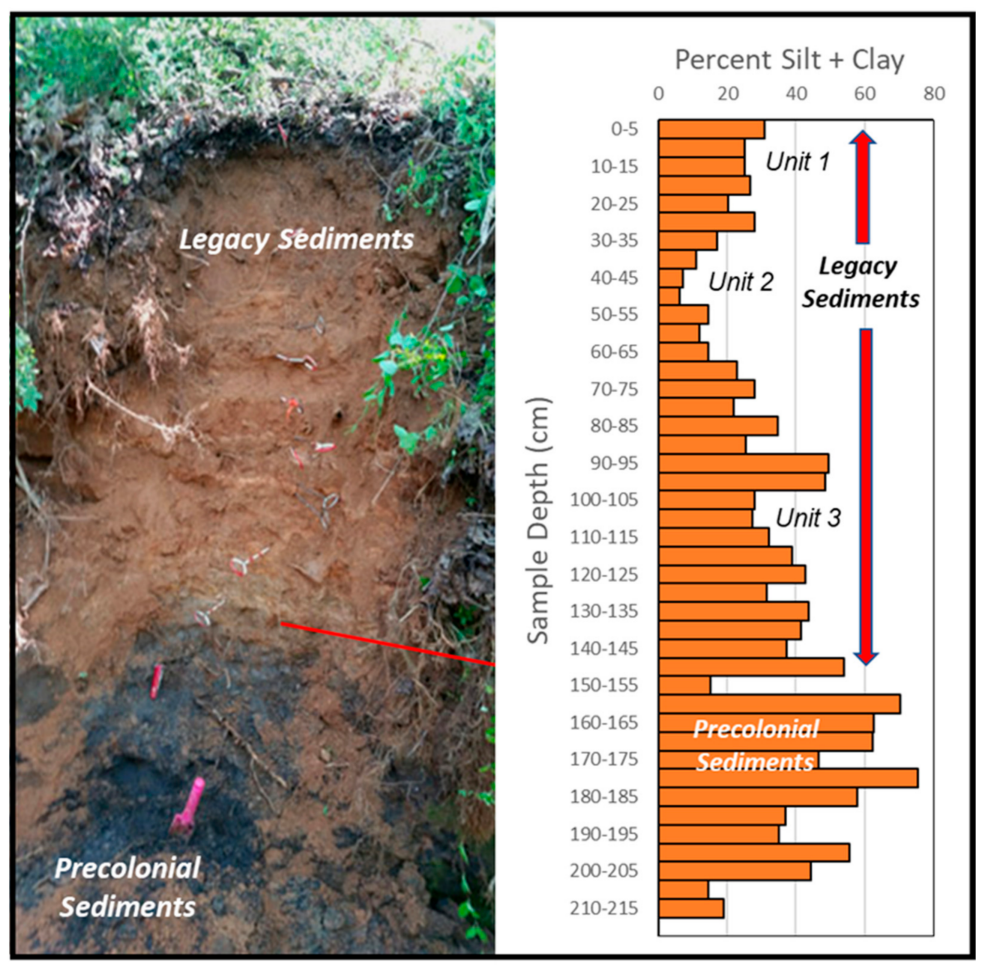

Figure 4. Variations in the percent of silt and clay in alluvial deposits described in the channel banks near the mouth of the Big Harris Creek project area (BHT3, Figure S1). Graph and photograph show the finer-grained, more indurated nature of the precolonial sediments, and occurrence of commonly observed sandy strata within the legacy sediments (figure from Miller et al. [25]). 
The legacy deposits ranged from 0 to more than $2 \mathrm{~m}$ in thickness and, along Stick Elliott Creek, varied primarily as a function of the topography of the precolonial surface (Figure 3F). The precolonial surface appears to have been primarily controlled by erosional processes, as indicated by (1) the abrupt erosional contact between the precolonial and legacy sediments (Figure 2A,B) and (2) the incorporation of dark, organic-rich "clasts" of precolonial sediments into the basal unit of the legacy sediments.

Many Cleveland County farmers were early adopters of terracing and other soil conservation practices (e.g., contour farming) as a response to extensive upland erosion. However, the terraces within the Big Harris Creek project area (Figures 1 and 5) were not constructed until the mid-twentieth century, after or at the end of the cotton growing era. In addition, by the early 1930s, farmers, including Mr. Clemmie Royster, who owned a significant part of the watershed at the time, began to shift away from cotton to pasturage and turkey farming, a trend that continued through the 1940s and 1950s.

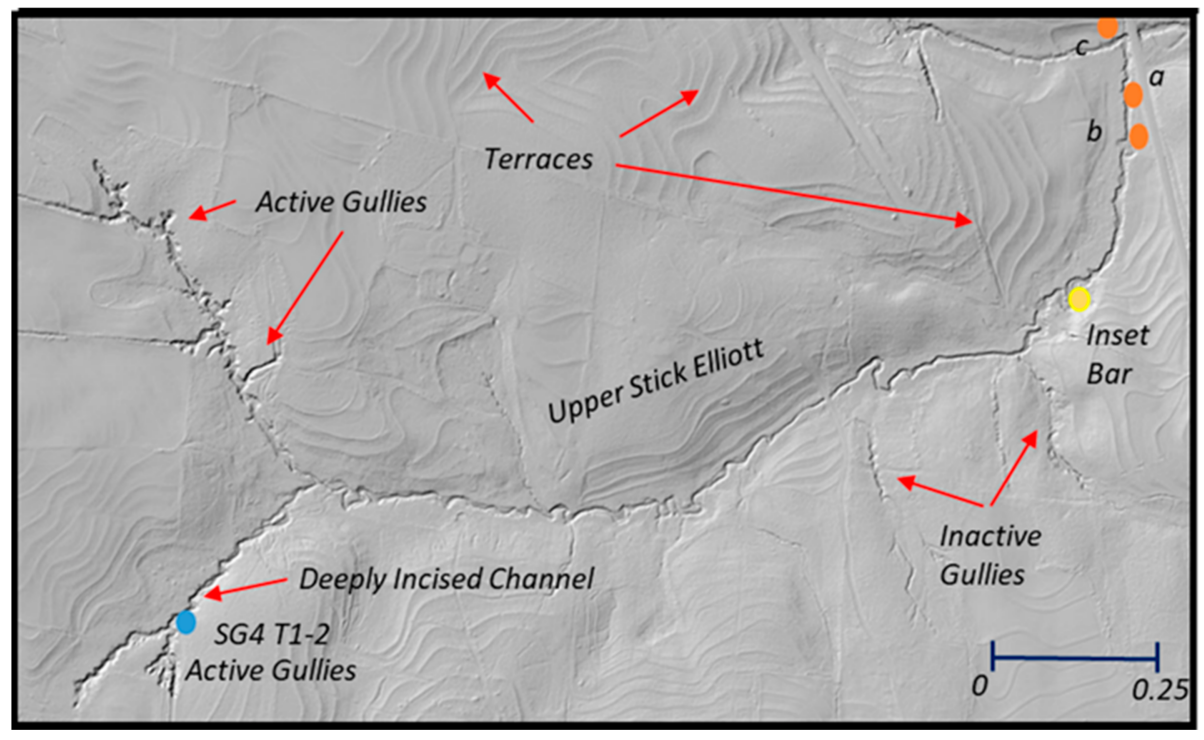

Figure 5. LiDAR DEM showing detailed view of geomorphic features along Stick Elliott Creek. Lettered orange circles represent the locations of photographs shown in Figure 2; blue circle represents inset terrace with dated trees. LiDAR DEM from the North Carolina Spatial Data Download Center (https:/ / sdd.nc.gov/, accessed on 10 October 2019).

Historic records obtained from other parts of the southeastern piedmont suggest that the conservation measures reduced soil erosion, an observation supported by dendrochronologic data collected in the Big Harris Creek basin [7]. More specifically, many of the oldest trees on the valley floor, which were dated using dendrochronologic methods, appear to have germinated after the mid-1950s (Figure 6), suggesting that the reworking of the valley floor surface by floods and the deposition of legacy sediments during overbank events had declined to a rate that allowed for the increased germination and growth of riparian trees. Deposition on the floodplain surface may also have declined in response to channel incision along mid- and downstream reaches of the channel network. The determined age of trees growing on the surface of terraces inset within the incised channel (e.g., at Site SG4, Figure 5 and Figure S2) indicates that downcutting, presumably in response to declining sediment loads, had begun by the early 1940s and 1950s, and ultimately exposed both precolonial and legacy sediments along the channel banks [25]. The examination of sequential aerial photographs and Google Earth images showed that land-use/land-cover changes since the 1960s were relatively minor and had a limited impact on channel form. 

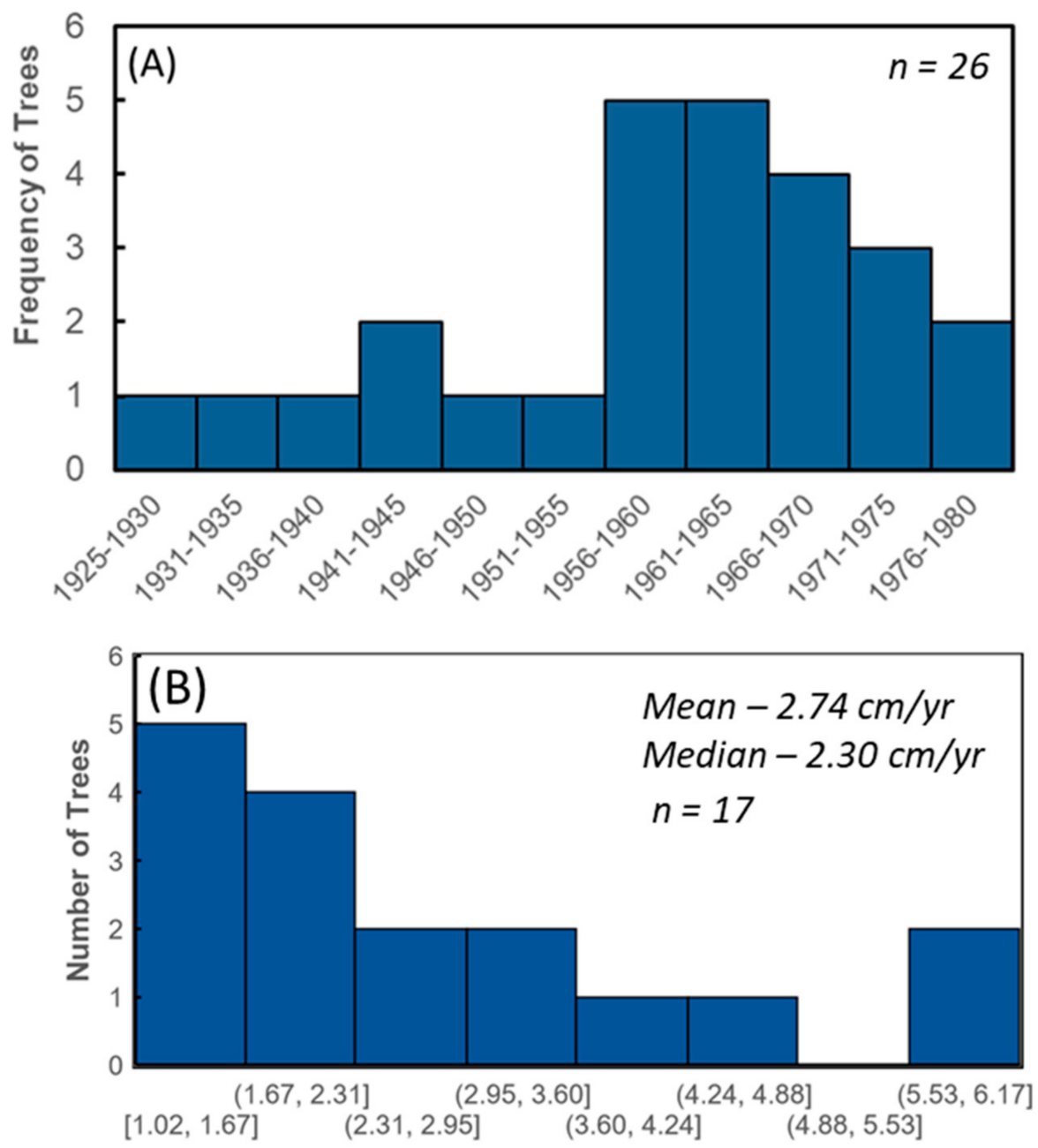

Range of Erosion Rates (cm/yr)

Figure 6. (A) Histogram showing the variation in the approximate age of the trees on the valley floor of entrenched alluvial channels. Age does not account for collection of tree cores at $1 \mathrm{~m}$ above ground. Exact date of germination is likely to be $2-5$ years prior to date shown; (B) rates of bank erosion estimated from tree age and width of exposed tree roots from channel banks. Includes trees from along Stick Elliott Creek, Upper Big Harris Creek, and Royster Creek. Figure updated from Miller et al. [25].

\subsection{Spatial Variations in Channel Morphology and Geomorphic Response to Disturbance}

In spite of being a relatively small headwater basin, the differences in the type and magnitude of the responses during the ADE described above (Figure S4) resulted in significant spatial variations in the morphological framework of the channel and valley system that existed prior to restoration in 2017-2018. These spatial variations were categorized and mapped in the form of seven distinct process zones (Figure 1), briefly described in Table 1. Two of these process zones represent gullies or gully-systems that were presumably created during the period of cotton production, and are evident on the LiDAR DEMs (Figures 1 and 5). The majority of these gullies, referred to as inactive gullies (Figure 1), are located on hillslopes, typically terminate downslope on the valley floor, and have become stabilized since their formation by the re-growth of vegetation (e.g., forest cover) on the gully bed and banks (Figure S5). These gullies show little evidence of recent erosion. Active gullies, however, remain in the basin (Figures 1 and 5). The majority of active gullies extend upslope from existing low-order channels, and occur in concave-up topographic lows devoid of a distinct channel (called an unincised ephemeral channel, Figure 1). In most cases, active gullies are linked downstream with "deeply incised channels" and terminate 
upstream in an amphitheater-shaped headcut (Figure 5) that is migrating upslope. These active gullies are often entrenched more than $5 \mathrm{~m}$ into the hillslope materials, creating steep banks; the floors of these gullies tend to be relatively flat (Figure 3A). The occurrence of dark, organic-rich precolonial soils at the top of many headwater gullies, and the presences of terraces with trees dating to the early 1940s and 1950s within the downstream deeply incised channels into which the gullies enter (Figure 3B), indicate that gully formation and the incision of these headwater drainages were coeval and likely occurred during the late 1800 s or early 1900s (during commercial cotton production).

Deeply incised channels primarily occur in upstream areas of the drainage network, but are not uniformly distributed throughout the catchment; they are only found in three of the eight tributary subbasins (Figure 1). Morphologically, deeply incised channels represent reaches where the channel has incised to depths in excess of $4 \mathrm{~m}$ below the valley floor, creating steep, locally unstable banks (Figure 3B,C). Alluvial valley fill is limited within these reaches. Where present, older (precolonial) alluvium occurs as narrow $(<\sim 5 \mathrm{~m})$, discontinuous accumulations that form a surface that abuts relatively steep hillslopes.

Lateral channel migration within the deeply incised channel reaches following incision has been limited ( 10-15 m, Figure 3B,C), presumably by the bank materials, which are predominantly composed of erosionally resistant upland soils, sediments, and saprolite (similar to Figure 2C), as well as by the height and volume of material that must be eroded and transported out of the reach during lateral migration. The lateral migration that has occurred has allowed for the deposition of legacy sediments that are associated with small inset fill terraces or floodplains within the incised trench, rather than on the valley floor.

Morphological similarities between active gullies and deeply incised channels (Table 1) may allow the former to be mis-identified as a pre-disturbance stream reach (at least one was for Big Harris Creek). The active gullies, however, differ in several important ways to the deeply entrenched channels identified and mapped for the Big Harris Creek project area, including (1) the gullies are historic features that did not exist prior to European settlement, (2) they are often characterized by flow magnitudes and frequencies that differ from adjacent meandering channels because of differences in drainage areas, (3) they lack fluvial landforms and in-channel features such a floodplains and pool and riffle sequences, and (4) they differ from meandering streams in the nature of the surface water-groundwater interactions that are required for many biological functions. Restoring such systems to a meandering, perennial system that is hydrologically linked to a newly created floodplain will be difficult at best along gullies as the effort would involve developing a channel where one, until relatively recently, did not exist, and within a local geomorphic and hydrologic setting that may not be conducive to the maintenance of a meandering stream.

The sediment generated during gully formation and the incision of deeply incised channels was transported downstream where it was re-deposited as legacy sediments on the valley floor and within the channel producing 1 to $>2 \mathrm{~m}$ of channel aggradation (Figure S4) (evidence for the linkage between upstream incision and downstream aggradation is discussed in more detail below). The deposition of these legacy sediments was not uniform throughout the watershed, but predominantly occurred along wide, lower gradient reaches of the valley system where precolonial alluvial deposits were prevalent (mapped alluvium in Figure 1).

Aggradation was followed by channel incision, producing an entrenched channel bound by alluvial deposits composed of both precolonial and legacy sediments. Although not well constrained, stabilization of the valley floor as indicated by increased tree germination (Figure 7) suggests that incision primarily occurred from the late 1940s through the 1960s. Incision, however, is continuing to occur, albeit at a slow rate, in some locations as indicated by knickpoints in resistant bedrock (Figure S6). These bedrock outcrops form local base level controls that help determine the degree of upstream degradation. The depth of incision has generally been on the order of 1 to $2 \mathrm{~m}$ where it was measured along the drainage network (e.g., at the described stratigraphic sections (Figure 1, Table S1) or, in more detail, along the longitudinal survey conducted within the lower reaches of Upper 
Stick Elliott Creek, Figure 3F). In the latter case, bedrock outcrops form topographic highs of more limited incision along the channel (Figure 3F).

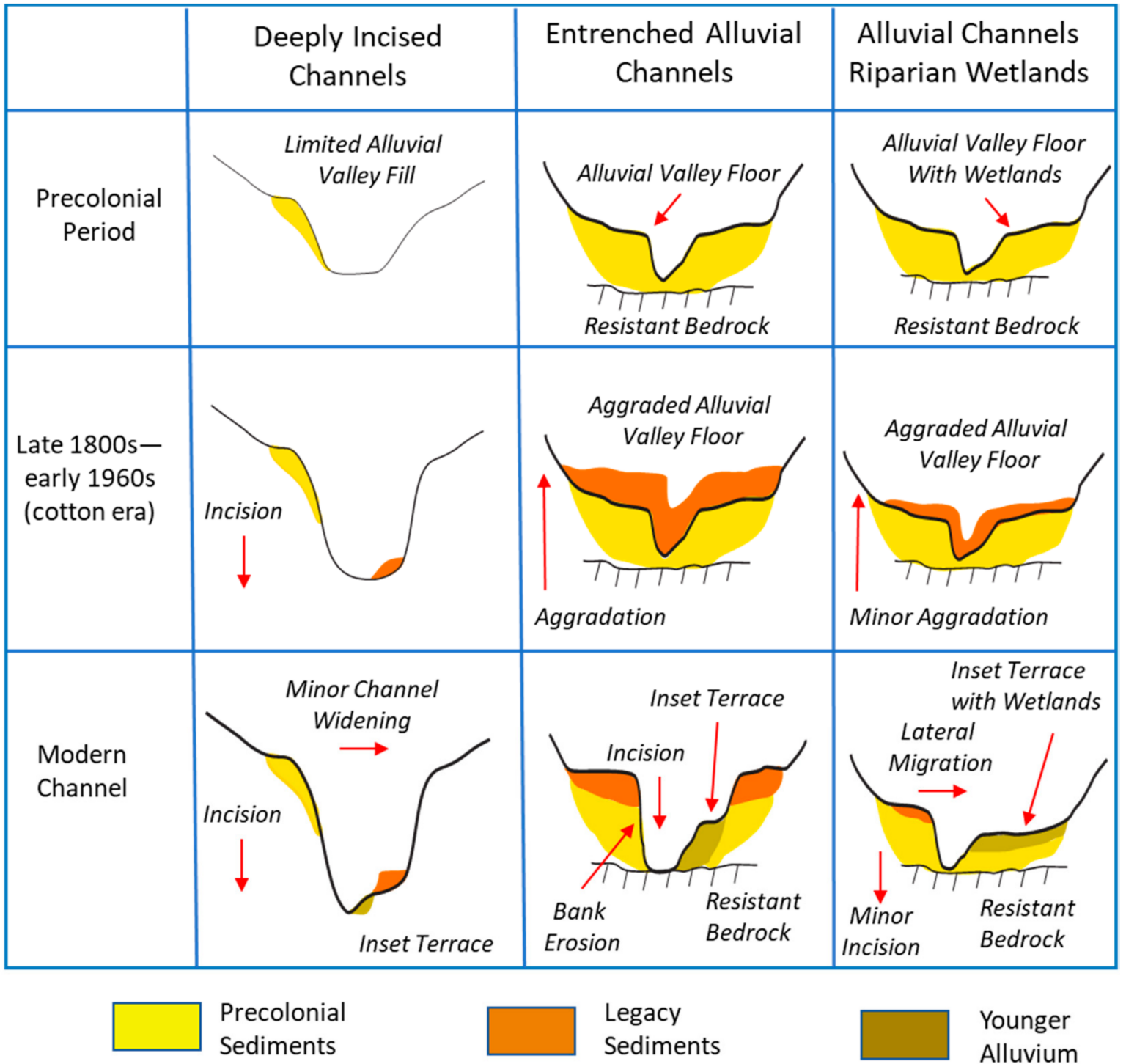

Figure 7. Schematic of channel and valley evolution since European settlement along the predominant process zone types in Big Harris Creek. Evolutionary pathways based primarily on topographic and stratigraphic data collected along the drainage network.

A few short reaches of the drainage network within the Big Harris Creek basin consisted of alluvial reaches with riparian wetlands. While the banks of these process zones were dominated by precolonial and legacy sediments, the channels consistently contained local outcrops of resistant bedrock that appears to have reduced the magnitude of channel incision (as discussed in more detail below). Lateral migration of the channel following the mid-1900s, however, has been significant, locally exceeding 20 to $25 \mathrm{~m}$ (Figure 3D).

\subsection{Channel Evolution in Response to Historic Land-Use Changes}

Given our imprecise understanding of the morphological, hydrological, and process characteristics that should be applied to create newly restored stream channels, one of the most difficult challenges of restoration is to appropriately parameterize restoration design [32]. The typical approach to parameterization involves the modification of channel morphology to obtain a stable state as perceived for a reference system that serves as a 
guiding target in terms of channel dimensions, planform, and gradient $[7,44-46]$. The use of such morphologically targeted approaches has become the topic of considerable debate [47-51], in part because it fails to adequately create a dynamic, continually changing river system that is required for many ecosystem functions and services [52]. Rather, the primary goal in many cases is to produce a geomorphically stable channel. In fact, many mitigation banking systems are based on achieving geomorphic stability [52].

Nevertheless, the need to focus more on ecosystem functions and less on geomorphic stability (in which the channel is effectively locked in place) is increasingly being recognized as an essential component of ecological restoration, and requires the creation of a dynamic, self-sustaining system $[35,36]$.

Recent studies have argued that the development of a dynamic, self-sustaining system should be based on the natural range of variability in channel and valley form over a time scale that captures the geomorphic responses associated with both natural and human-induced disturbances as determined by historical analyses [27,53]. In essence, such analyses document the changes in river form and processes that result from threshold crossing events, and that result in river metamorphosis (as envisioned by Schumm [54]). These responses have often been presented in terms of channel evolution models (CEMs), which describe the stages through which a river will progress in response to a disturbance. Historically, CEMs have most commonly been used to describe the evolutionary pathway of single-thread rivers during and following an episode of incision, particularly in response to base level lowering or channelization [55-58]. Here, we refer to such descriptions as the classical model of channel evolution (after Booth and Fischenich [59]). The intent is to subdivide the response of the river into relatively simple morphological stages and processes that can be used, among other purposes, to (1) assess stream conditions [59], (2) develop guidelines into the type of rehabilitation practices that can be applied [56], (3) determine the general nature or type of channel that should be designed given the river's current state $[44,45,60]$, and (4) predict the trajectory of future stream channel adjustments $[53,59]$.

The classical model mentioned above is perhaps the most widely used model by restoration practitioners. This CEM includes five stages through which an incising singlethread river progresses from a stable channel to a renewed channel in a quasi-equilibrium state at a lower level (Figure S7). Specific stages in the progression include the following: (1) A degrading channel where bank heights have yet to exceed the critical height needed for mass wasting processes. Thus, the banks remain stable (Type I channels, Figure S7). (2) A degrading channel where bank heights exceed the critical bank height needed for mass wasting, producing bank instability (Figure S7, Type II). (3) An increase in channel width by bank failure, which may be accompanied by minor channel aggradation that occurs in response to a lowering channel slope that reduces the channel's sediment transport capacity (Figure S7, Type III). (4) A continued phase of bank erosion via mass wasting, but at a reduced rate. The sediment transport capacity of the channel during this stage of development is exceeded by the sediment supply, resulting in channel aggradation. The channel is approaching a new quasi equilibrium condition and sediment begins to accumulate along the channel margins (Figure S7, Type IV). Finally, (5) new quasi equilibrium channel possessing a stable alluvial bed and banks. Channel migration also produces a new floodplain inset within the constructed trench (Figure S7, Type V). The CEM as presented above envisions a systematic transition in the dominate processes from a period of rapid incision to a phase of reduced incision accompanied by bank erosion and channel widening, to a period of continued widening and channel bed aggradation. The sequence ends in a quasi-equilibrium channel in which both the channel and floodplain are inset below the original valley floor (Figure S7).

Since these earlier studies, it has become apparent that a single CEM cannot be universally applied to an entire catchment because of reach-scale differences in the nature and sensitivity of the channel to adjust to a disturbance as governed by such factors as sediment supply, local hydrologic regime, channel and valley gradient, the nature of the bed and 
bank materials, and vegetation cover [20], among other parameters. Herein, we examine the channel evolutionary changes associated with the ADE that was initiated by land-use changes in the Big Harris Creek basin for the major types of process zones, including deeply incised channels, entrenched alluvial channels (within narrow and wide valleys), and alluvial channels with riparian wetlands (Figure 1; Table 1). The evolutionary changes in the valley and channel system (described in the previous section) produced spatial variations in the boundary conditions that control the contemporary channel processes and adjustments to disturbance. Specific boundary conditions that have been described in previous studies include valley morphology (slope and width), sediment and water fluxes, vegetation cover, and the ease with which geomorphic adjustments are propagated along the drainage network [53,61,62].

While deeply incised channels are located in tributary subbasins, their distribution cannot be entirely explained by the position along the drainage network. In fact, field observations suggest that they are associated with the three tributary basins whose channels lack significant outcrops of resistant bedrock; rather, they are underlain and/or cut into highly weathered saprolite. Other distinguishing characteristics include the limited occurrence of precolonial valley fill deposits, and their high degree of channel bed degradation. Royster Creek, in which the channel has incised on the order of 5-6 m (Figure 3C), depending on location, is a good example. Field observations failed to identify any resistant outcrops of bedrock along the channel, although the channel floor and lower banks were often formed in highly weathered saprolite (e.g., sites RC-1, RC-2, Table S2).

Degradation presumably started with the onset of commercial cotton production. Simon and Hupp [57] found that, along alluvial channels in western Tennessee, downcutting was initially rapid, and then decreased as the bed reached an asymptotic elevation of no net change. Early incision along the deeply incised channels in the Big Harris Creek basin was also likely to have been rapid. While not widespread, narrow, spatially discontinuous inset terraces occur within the incised trench (Figure 3B,C), which are vegetated by trees dating back to the late 1940s to 1960s (e.g., SG-4, Table S3). These inset terraces indicate local channel widening and lateral migration occurred prior to a renewed phase of incision that resulted from the decline in sediment influx following the construction of upland (hillslope) terraces and the transition from cotton to pasture and forests. The presence of existing knickpoints and knickzones along the channel, combined with multiple sets of more recent inset strath terraces (e.g., along Royster Creek), indicates that incision continues to be a significant process. We believe, however, that the rate of incision has become more limited in comparison with earlier periods of downcutting as the channel cut through the unconsolidated upland sediments, often composed of cohesive sands (e.g., in Figure 2C) and reached the more erosionally resistant saprolite found in the channel bed and lower banks (see, for example, RC-1, RC-2, Table S2). Channel widening and bank erosion has also occurred locally along these process zones since the mid-1900s, but again is likely to be limited by the common occurrence of saprolite and cohesive upland sediments and soils in the steep channel banks. Thus, over a period of more than 120 years, channel evolution has been dominated by multiple episodes of incision, which were occasionally accompanied by bank erosion and channel/trench widening. In combination, these processes led to the formation of local, discontinuous inset terraces along the channel (Figure 7).

The evolutionary trajectory and morphological character of the channels differ significantly from the deeply incised channels described above (Figure 7). After the transition to cotton cultivation, legacy sediments were deposited on the valley floors (and thus on top of precolonial deposits) along the entrenched alluvial channels. Channel and valley aggradation were followed by channel incision during the mid-1900s, exposing both legacy sediments and precolonial deposits in the channel banks. The modern channel bed is usually characterized by a layer of unconsolidated sediments of varying thickness that overlies bedrock. In some locations, the unconsolidated sediments are sufficiently thick to form pool and riffle sequences; in other areas, bedrock is exposed along the channel (Figure S6). Following degradation that occurred in the mid-1900s, the primary process within these 
reaches has been bank erosion; bank erosion rates since the mid-1900s have been estimated, using dendrogeomorphic methods, to average $2.74 \mathrm{~cm} /$ year (Figure 6B). The general lack of an inset floodplain along the channel (Figure 3E), except at pronounced meander bends, indicates that bank erosion primarily resulted in channel widening. Thus, channel evolution since the mid-1900s has roughly followed the initial stages of the classical CEM, in that widening was accompanied locally by the minor accumulation of sediment on the channel bed (Figure 7). Sediment is also deposited on the valley floor during overbank flooding.

Both past and current changes in channel morphology along entrenched alluvial channels were and continue to be linked to the geomorphic responses that occur in upstream areas of the catchment. For example, the onset of cotton production appears to have led to the upstream development of gullies and the incision of deeply incised channels. Sediment produced in these areas was then transported downstream and directly led to the channel and valley floor aggradation observed along the entrenched alluvial channels (Figure S4). This linkage is particularly pronounced along Upper Stick Elliott Creek (Figure 1), where an inset terrace is located along deeply incised channels in headwater reaches (Figure 3B). The surface of this terrace possesses trees that were dated from 1945 to 1952 at site SG-4 (Table S2), as well as younger trees that were not dated. Downstream, trees growing on legacy sediments that immediately underlie the valley floor date to the early 1960s (Table S2), suggesting a coeval period of formation (within the accuracy of the available dendrochronologic data). The downstream transition point from degradation to aggradation can be viewed as an energy fulcrum where the transport capacity of the channel upstream of the fulcrum exceeded the available sediment load, resulting in degradation, whereas downstream of the fulcrum, the available energy was less than that needed to transport the incoming sediment, resulting in aggradation. The linkage shows that there is a high degree of landform connectivity between the two types of process zones. Put differently, geomorphic responses (incision in this case) were propagated downstream throughout the project area.

A similar spatially divergent event also occurred following incision of the entrenched alluvial channels in the latter part of the 1900s. In this case, incision appears to have been locally and spatially limited. Along the upstream reaches of the entrenched alluvial channels of Upper Stick Elliot Creek, for example, a terrace composed of sand-sized sediment is inset below the valley floor and discontinuously occurs along the channel (USE-6, Figure S1). The surface of the terrace is devoid of older trees (< 30 years), suggesting it post-dates the initial period of channel incision that occurred during the 1940 to 1960 s. We speculate that the terrace was formed by a minor, short-lived aggradational and degradational event that occurred along upstream reaches of many entrenched alluvial channels (e.g., Stick Elliott Creek). More specifically, the inset fill terrace is thought to represent a form of complex response (in the form described by Schumm [63]) where continued upstream gully migration and incision within the deeply incised channels during the latter 1900s generated enough sediment to locally and temporarily exceed the transport capacity of the channel downstream. The produced deposit was subsequently entrenched as upstream reaches adjusted to incision and sediment loads declined. The temporary and localized deposition of sediment during a longer and spatially more extensive episode of downcutting is not unusual and is often referred to as a non-linear response [64,65]. It is non-linear in that the incision did not follow a single trajectory, but was affected by an episode of deposition.

As noted above, the combined geomorphic histories of the deeply incised channels and the entrenched alluvial channels show the following: (1) there is a high degree of landscape connectivity along the drainage network such that upstream responses are propagated downstream and, in doing so, the response may result in opposing processes (e.g., aggradation as opposed to degradation); and (2) the evolution of the entrenched alluvial channels may be non-linear, and short-lived episodes of aggradation may be imposed on a longer-term trajectory of incision. Channel evolution was also influenced by the occurrence and erosional resistance of the underlying bedrock. 
The influence of the underlying bedrock was particularly pronounced along alluvial channels with riparian wetlands (Figure 1). The bedrock appears to have had three significant effects on channel evolution. First, the formation of bedrock knickpoints, along with the lack of bedrock in the channel banks, and the overall depth of incision as shown on the channel cross-sectional surveys (Figure 3D), indicate that the magnitude of incision was limited after reaching the coherent (unweathered) bedrock. Rather, the predominant process was lateral channel migration, which formed a new floodplain set below the valley floor (Figure 3D). Second, the general lack of significant incision appears to have allowed for more frequent overbank flooding, and a closer link between channel and floodplain hydrology. Flood debris is extensively located on the valley floor along the reach. Third, the bedrock consists primarily of metamorphic rocks, such as metamorphosed felsic rocks (e.g., granites) and micaceous schists and phyllites. These rock types are generally impermeable unless extensively fractured, and allow water to "pond" on top of the bedrock, thereby creating the hydrologic conditions required for the formation of wetlands (i.e., water tables at or near the ground surface). A key point derived from the above data is that channel evolution along this process zone type differs from the other process zones. The response was dominated by a relatively minor incision followed by more extensive lateral channel migration and floodplain development once degradation impinged on bedrock.

Spatial differences in morphological adjustments and pathways, such as those described above, are often characterized in terms of landscape sensitivity (or, simply, sensitivity), which Brunsden and Thornes [61] defined as the likelihood that a given change in the controls of the system will produce a sensible, recognizable, and persistent response in the landform of interest. Miller et al. [66] and Chambers et al. [67] applied the concept of sensitivity to small upland watersheds in the Great Basin of central Nevada, and argued that sensitivity could be qualitatively categorized as a function of the rate and magnitude of the responses to past disturbances. In other words, the likelihood that a given reach will incise, for example, could be defined by its sensitivity to incision as judged from the reach's past geomorphic history. However, past responses are not necessarily a perfect guide to future responses, and any assessment of the system's current sensitivity requires an understanding of the factors that control sensitivity in general. Chambers et al. [67] found that, in central Nevada, increases in both basin and reach-scale sensitivity were associated with channels characterized by high stream power, large sediment supplies, and channel bed and bank materials that could be easily eroded during moderate floods. A similar combination of factors was identified by Miller and Kochel $[68,69]$ to have controlled the stability of reconstructed channel reaches and the performance of instream structures within the Blue Ridge and Piedmont physiographic provinces of North Carolina. In this case, the potential risk of project failure as defined by significant (threshold crossing) changes in channel form along reconstructed channels were associated with streams possessing high stream powers, large sediment supplies and transport rates, and easily eroded bank materials.

The implications of sensitivity to restoration can be illustrated for the two predominant types of process zones in the Big Harris Creek basin. Historically, deeply incised channels exhibited a high degree of sensitivity to incision as demonstrated by the significant depths of downcutting that occurred following the adoption of cotton as a cash crop. As degradation progressed, the confined nature of the deeply incised channel reaches presumably increased, producing relatively high stream powers along the contemporary channels. While increases in stream power would typically increase reach-scale sensitivity, the influence of the potentially elevated transport capacity appears to have been counteracted by relatively resistant bed and bank materials that currently limit both incision and bank erosion. The potential for the channel within these reaches to undergo rapid change is, in general, reduced by the cohesive, highly weathered upland sediments and soils (including saprolite) that form the channel perimeter (e.g., RC-1, RC-2, Table S1). These reaches, then, currently exhibit a relatively low sensitivity to future disturbance. In contrast, entrenched alluvial channels represent highly dynamic reaches that have exhibited significant episodes of channel bed aggradation and degradation, valley floor deposition, and bank erosion. 
Currently, the potential of additional incision is locally controlled by erosionally resistant bedrock exposed in the channel floor that serves as local base level (grade) controls (e.g., along the lower reaches of Upper Stick Elliott Creek, Figure 3F). Moreover, the occurrence of unconsolidated precolonial and legacy sediments in the channel banks, including layers of loose sand in the legacy deposits (Figure 2, Table S2), has allowed for high rates of bank erosion (Figure 6). In fact, monitoring data collected along entrenched alluvial channels show that downstream reaches of Big Harris Creek possess some of the highest suspended sediment loads reported for the piedmont of the southeastern United States [25]. These sediments are locally deposited and stored on the valley floor during overbank flooding. In combination, the high potential for significant adjustments via bank erosion and lateral channel migration, combined with the potential for the reach to undergo both aggradational and degradational episodes when perturbed, suggest that these stream segments are highly sensitivity to both natural and anthropogenic disturbances.

Morphologically, the relatively wide valley floors of the entrenched alluvial channels, combined with their reduced depths of entrenchment, in comparison with the deeply incised channels, allow for the application of a broader range of channel modifications during a rehabilitation/restoration project. In fact, it is the entrenched alluvial channels/valleys that are most often targeted for restoration. This, then, sets up a paradox in that the reaches that are morphologically most amiable to current restoration approaches possess the highest sensitivity to respond to future disturbances within the basin.

\subsection{Influence of Channel Evolution on Restoration Design and Performance}

The classical model of channel evolution was developed for alluvial rivers possessing erodible bed and banks. The majority of restoration projects, however, are conducted on small, headwater basins where flow conditions are more manageable [52] and that are similar to Big Harris Creek. The channel system in Big Harris Creek has roughly evolved in accordance with the classical CEM, characterized by incision followed by bank erosion and channel widening. However, the occurrence of bedrock along the channel floor of Big Harris Creek has altered the specifics of channel evolution in that the depth of incision does not typically create bank heights that exceed the critical heights needed for bank failure by rotational or planar slides. Rather, bank erosion is dominated by a combination of corrasion and slab failures that is directly related to bank stratigraphy. Below the upper most $20-35 \mathrm{~cm}$ of the ground surface, the more highly stratified legacy sediments are primarily eroded by corrasion, in which individual grains are moved by the adjacent stream flow. The erosion of these sediments produces a concave-in (or depression) within the bank profile that resides between the upper, more cohesive sediments that are subject to slab failure, and the lower, more resistant precolonial deposits (Figure 8). In many areas, the upper, darkcolored precolonial deposits form a "ledge" along the bank, illustrating their more resistant nature (Figure 8 and Figure S8). The difference in resistance does not appear to be related to overall differences in grain size. For example, the percentage of fine sediment (silts and clays) generally controls the degree of unconsolidated sediment cohesion and erodibility. On average, a slightly larger percentage of silt and clay occurs in the precolonial deposits (Figure 9) than the legacy sediments, but the difference was statistically insignificant ( $t$-test, $p=0.05)$. The primary difference between the two units is in their degree of decimeter-scale stratification (Figures 2 and 4; Table S1). The upper precolonial deposits possess little stratification, but consist of massive, fine-grained, cohesive sediments. In contrast, the legacy deposits are highly stratified with individual layers that vary in grain size from slightly cohesive loams to loose sands (Figure 4; Table S1). Resistance of the precolonial deposits is also promoted by coarse-grained gravels near the base of the banks and, to a much lesser degree, by tree roots and vegetation (Figure 8). Interestingly, coarse gravels are generally absent from the legacy deposits (Table S1), presumably because they were primarily derived from the erosion of upland soils and sediments as well as the upper precolonial deposits. 


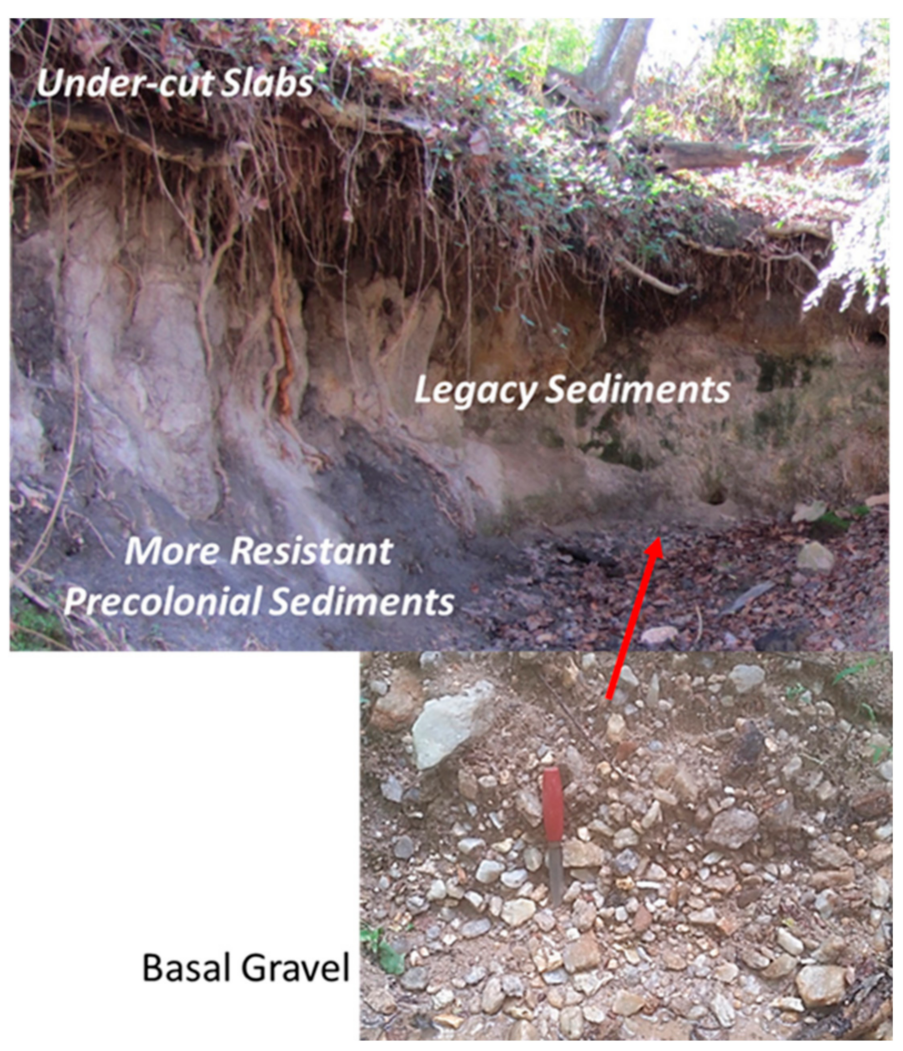

Figure 8. Commonly observed morphology of alluvial channel banks. Note undercut surface materials composed of legacy sediments and stabilized by roots. More resistant, dark colored precolonial sediments overlie alluvial gravels located at the base of the bank. Bank erosion occurs by combination of corrasion of fine particles creating an undercut section, and subsequent failure of slabs by cantilever mechanisms.

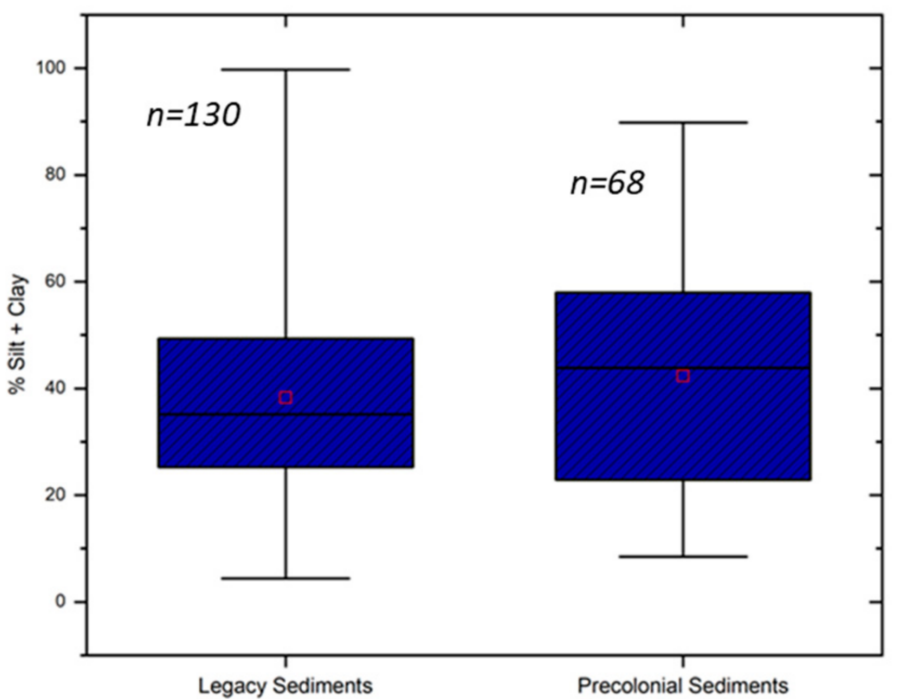

Figure 9. Comparison of the fine-grained sediment content of the precolonial and legacy sediments along entrenched alluvial channels. Box represents $25-75 \%$ of samples; horizontal line is the mean; small square is median; whiskers represent maximum and minimum values.

In light of the above, channel evolution along the entrenched alluvial channels of Big Harris Creek differs from the classical model in several important ways. First, the depth of incision is dictated by the underlying bedrock, and the rate of incision may not decline as 
a quasi-equilibrium state is achieved (as noted by Simon and Hupp [57]). The potential magnitude of incision, in both the past and future, can be determined by assessing the elevation of the underlying bedrock. Incision along the entrenched alluvial channels of Big Harris Creek never reached the depths required to initiate bank failure by rotational or planar sliding. Thus, bank erosion is likely to be dominated by corrasion and localized slumping, rather than larger scale rotational or planar slides.

Second, both the processes and rates of bank erosion during channel evolution were strongly influenced by local bank stratigraphy. The rates of bank erosion will primarily be determined by the erosional resistance of the precolonial deposits at the base of the banks. Attempts to characterize bank stability and erosion rates using rather simple models that primarily consider bank heights and/or a single descriptor of bank material composition (e.g., the Bank Erosion Hazard Index, BEHI [70]) are likely to result in erroneous assessments. This argument is supported by data from the much larger Haw River in the piedmont of North Carolina, where Macfall et al. [71] found that the magnitude of bank retreat was not correlated to either bank height or the BEHI. Bank erosion and stability may be more appropriately determined using algorithms such as the Bank Stability and Toe Erosion Model (BSTEM, [72]), which allows for the analysis of stratigraphically complex banks and the assessment of bank steepening by bank toe erosion, which is likely to be of importance to bank stability where precolonial deposits occur. The cohesive nature of the precolonial deposits may also be of significance in determining the hydraulic geometry of the contemporary channel. Dunne [73] found that the critical shear stress required to entrain the cohesive bank toe material was a first-order indicator of the hydraulic geometry of fine-grained threshold channels.

The stratified nature of the entrenched alluvial channel banks also has significant implications for channel design. For example, channels developed as part of an ecological restoration project require a mobile channel with deformable banks. This follows, in part, because channel migration produces new habitats that are required from sustainable aquatic ecosystems. It is necessary, then, to construct banks that can be eroded, thereby allowing for channel migration, while maintaining a quasi-equilibrium form. Prior to European settlement, bank erosion and lateral channel migration were presumably limited by the cohesive nature of the floodplain sediments, and the coarse gravels found at the base of the banks (and overlying bedrock as describe above). In contrast, between about 35 and $60 \%$ of the modern channel banks are now composed of easily eroded legacy sediments (Table S1). Attempting to create a mobile, yet geomorphically stable stream where legacy sediments comprise the channel banks is likely to be difficult at best, given the ease with which loose, sandy sediments can be removed from the banks and from around root wads and other forms of bank treatment $[68,69]$. It should also be recognized that, during future disturbances in which sediment transport capacity is altered such that it exceeds sediment availability, the primary response will predominately involve bank erosion (e.g., channel widening and/or alterations in planform morphology), rather than rapid or significant incision. The possible exception is the case where a new channel is constructed at a higher elevation in an attempt to "reconnect" the channel to its floodplain. In doing so, the channel banks are likely to be primarily composed of legacy sediments, whereas the channel bed rests on the more resistant pre-settlement deposits (Figure 10). To date, the geomorphic impacts of significant flooding along Big Harris Creek have been limited, but where bank erosion has occurred, it was located along reaches where the channel banks were composed of legacy sediments (or reworked legacy sediments) (Figure 11a,b). 


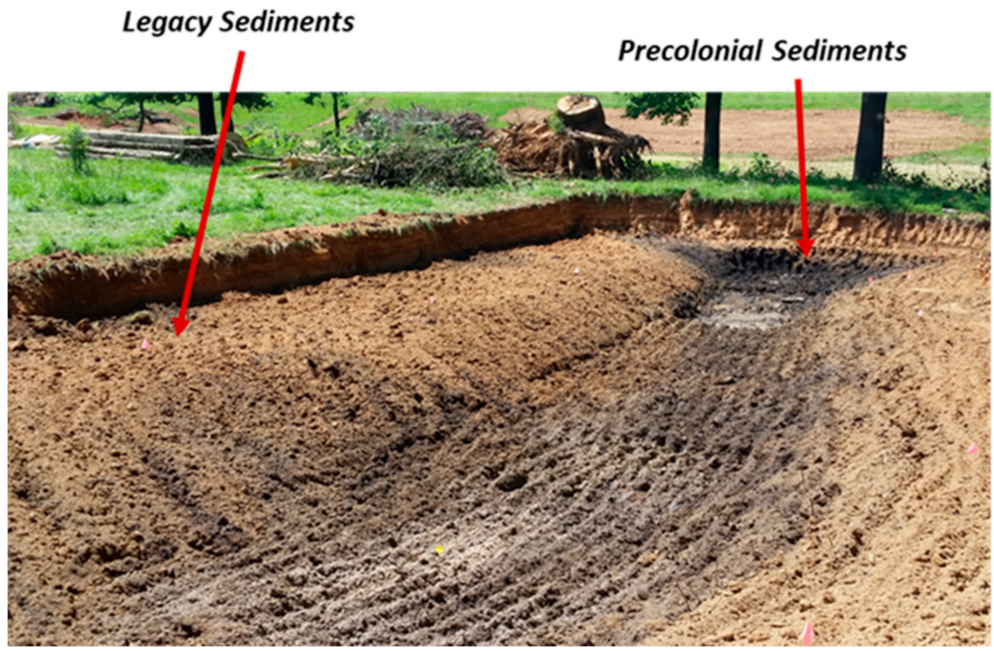

Figure 10. Channel construction along Stick Elliott Road. The banks of the newly constructed channel will consist of easily eroded legacy sediments, whereas the channel bed will rest on more resistant, and finer-grained, precolonial deposits.

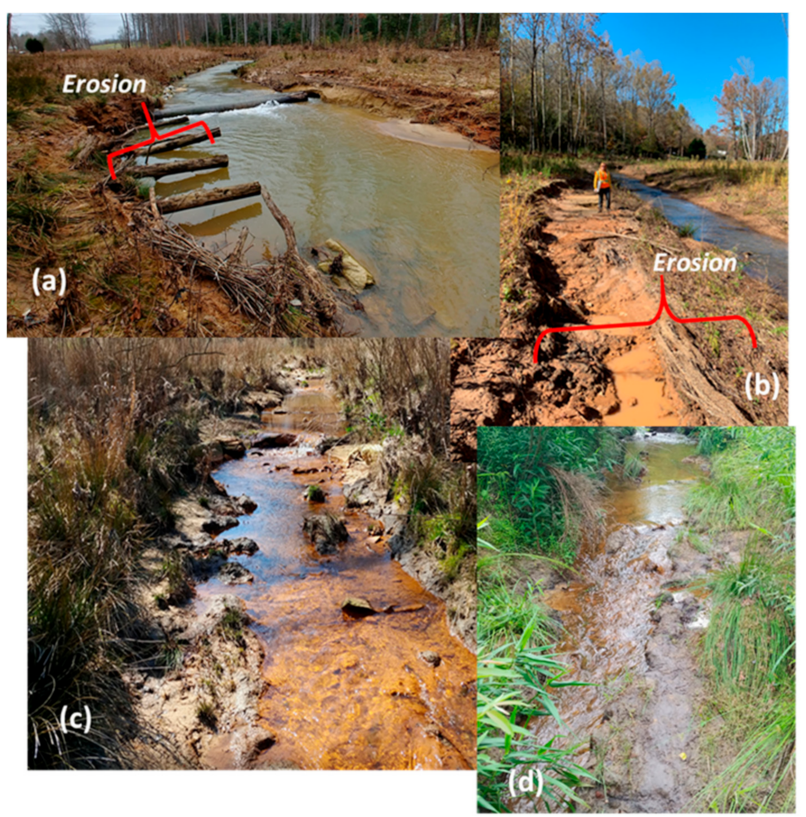

Figure 11. $(\mathbf{a}, \mathbf{b})$ Erosion that occurred along the lower reaches of Big Harris Creek near the downstream terminus of the project. Bank erosion was presumably enhanced by the relatively erodible nature of the sandy legacy deposits (or reworked legacy deposits) that form the channel banks; (c,d) exposed precolonial deposits along bed of reconstructed channel of Stick Elliott Creek. Note that knickpoints developed in the resistant precolonial deposits.

Channel evolution observed along entrenched alluvial channels also raises the question as to whether the construction of a new channel at a higher elevation is a sustainable approach. Paleochannels preserved within the precolonial deposits, combined with channel bed gravels at the base of the banks and that rest on the bedrock, show that the modern channel has downcut to the level that existed prior to cotton farming (see Figure 2A, for example). Where a new channel is constructed at a higher elevation between two reaches for which the bed elevation was not altered, the historical data suggest that the channel is likely to downcut and return to the channel bed elevation that existed both prior to European settlement and following the implementation of soil conservation measures and that was controlled by bedrock. Indeed, the reach along Upper Stick Elliott Creek that 
was constructed at a new elevation during the restoration program is currently incising, as indicated by several knickpoints developed in precolonial deposits and a channel bed generally devoid of loose, unconsolidated sediments (Figure 11c,d). While the depth and rate of erosion, as well as knickpoint migration, have been limited by the relatively high erosional resistivity of the precolonial deposits, we believe that degradation will continue until bedrock is encountered.

An alternative approach to address the potential problems cited above is to maintain the retarded by the deformable, yet erosionally resistant nature of the precolonial deposits. Thus, channel migration will occur, but presumably at more sustainable rates without the excessive use of hardened wood or rock structures. Moreover, legacy sediments have been shown to be an important source of suspended sediments to the channel that negatively impacts water quality [21,22,24,25]. Miller et al. [25], for example, argued that the relatively high sediment concentrations and loads measured along Big Harris Creek were at least partly due to the widespread occurrence of legacy sediments in the channel banks. The removal of legacy sediments from the immediate channel perimeter has the potential to not only decrease the rate of bank erosion (if the channel was raised to a new elevation), but improve water quality. Third, the created floodplain will likely be hydrologically reconnected to the channel, returning the system to a closer resemblance of its former hydrologic regime, including the development of riparian wetlands. Booth and Loheide [74,75], for example, examine the advantages and disadvantages of removing the legacy sediments to create riparian wetlands.

\section{Conclusions}

Most river restoration projects focus on small, headwater drainages, which account for more than $70 \%$ of total stream length in the continental United States [76] and tend to be more easily modified. Big Harris Creek is one such basin, and the site of one of the largest stream restoration projects in North Carolina. Like most rivers in the southeastern and eastern Piedmont physiographic province in the United States, it underwent an ADE in response to land-use changes in the late 1800s and early 1900s, followed by the implementation of soil conservation practices in the mid-1900s. In spite of its small size and the relatively uniform intensity of disturbance, geomorphic responses and reach-scale evolutionary pathways within the catchment varied significantly as a function of position along the drainage network, the valley width, and the erodibility of the underlying bedrock, among other factors. It is widely accepted that such historical, spatially variable changes in channel form and processes produce the framework for contemporary and future channel processes and adjustment mechanisms. However, time and financial constraints often limit the ability of practitioners to conduct detailed reach-scale assessments of the project basin. During this study, a qualitative analysis of the spatial variations in geomorphic responses during the ADE was undertaken using a combination of historical, stratigraphic, and LiDAR data. The analyses resulted in the characterization and mapping of specific reaches, referred to as process zones, that were dominated by similar landforms, processes, evolutionary pathways, and landscape sensitivity to disturbance. The developed understanding of historical alterations along the process zones can be used, among other purposes, to (1) assess current stream channel conditions and stability, (2) develop an understanding of the potential risks associated with channel modification at the reach-scale, (3) gain insights into channel design given the river's current form and bounding bed and bank materials, and (4) predict the trajectory of future stream channel adjustments.

In the case of Big Harris Creek, the controls of bed and bank material composition were particularly important along entrenched alluvial channels where resistant bedrock outcrops limited channel incision, and the mode and rate of bank erosion were controlled by the occurrence of easily eroded legacy sediments (often composed of loose sand layers) that overlie cohesive, erosionally resistant precolonial sediments. Practitioners designing reconstructed channels should carefully consider the potential risks of developing channel banks in legacy sediments (or fill composed of the legacy sediments). In contrast, the 
erosional resistance of the precolonial deposits, including the occurrence of basal gravels that overlie bedrock, suggests that they may allow for the formation of deformable banks needed for ecological restoration.

Supplementary Materials: The following are available online at https:/ / www.mdpi.com/article / 10.3390/geosciences11100423/s1, Figure S1: Location of described stratigraphic sections; Table S1: description of stratigraphic profiles; Figure S2: Location of dendrochronologically dated trees; Table S2: Summary of dendrochronologic data; Table S3: Summary of radiocarbon samples and dates; Figure S3: Photographs of exposed tree roots caused by bank erosion and used to determine bank erosion rates; Figure S4: Schematic diagram of aggradational-degradational episode; Figure S5: Photography of inactive gully; Figure S6: Photographic of typically bedrock channel reach; Figure S7: Classic Channel Evolution Model; Figure S8: Contrasting Erosion between Precolonial and Legacy Sediments.

Author Contributions: Conceptualization, J.R.M.; methodology, J.R.M., D.G. and L.S.P.; formal analysis, J.R.M., D.G. (dendrochronology), and L.S.P. (historical analysis); data curation, J.R.M.; writing—original draft preparation, J.R.M.; writing—review and editing, J.R.M., D.G. and L.S.P.; visualization, J.R.M.; supervision, J.R.M., D.G. (dendrochronology), and L.S.P. (historical analysis); project administration, J.R.M.; funding acquisition, J.R.M. All authors have read and agreed to the published version of the manuscript.

Funding: This research was funded by the North Carolina Division of Mitigation Services, DENR contract number 00461, and the Whitmire Endowment at Western Carolina University.

Data Availability Statement: The data presented in this study are available in Supplementary Materials.

Acknowledgments: The authors thank Kelly Ferri and Lionel Villarroel for the help in the collection of alluvial stratigraphic and survey data. The manuscript benefitted greatly from the constructive comments provided by three anonymous reviewers.

Conflicts of Interest: The authors declare no conflict of interest. The funders had no role in the design of the study; in the collection, analyses, or interpretation of data; in the writing of the manuscript; or in the decision to publish the results.

\section{References}

1. Knox, J.C. Floodplain Sedimentation in the Upper Mississippi Valley: Natural versus Human Accelerated. 37th Binghamt. Geomorphol. Symp. 2006, 79, 286-310. [CrossRef]

2. James, L.A.; Lecce, S.A. 9.37 Impacts of Land-Use and Land-Cover Change on River Systems. In Treatise on Geomorphology; Shroder, J.F., Ed.; Academic Press: San Diego, CA, USA, 2013; pp. 768-793. ISBN 9780080885223.

3. Leigh, D.S. Multi-millennial Record of Erosion and Fires in the Southern Blue Ridge Mountains, USA. In Natural Disturbances and Historic Range of Variation: Type, Frequency, Severity, and Post-Disturbance Structure in Central Hardwood Forests USA; Greenberg, C.H., Collins, B.S., Eds.; Springer International Publishing: Cham, Switzerland, 2016; pp. 167-202. ISBN 9783319215273.

4. Kemp, D.B.; Sadler, P.M.; Vanacker, V. The Human Impact on North American Erosion, Sediment Transfer, and Storage in a Geologic Context. Nat. Commun. 2020, 11, 6012. [CrossRef]

5. Happ, S.C.; Rittenhouse, G.; Dobson, G.C. Some Principles of Accelerated Stream and Valley Sedimentation (No.695); US Department of Agriculture: Washington, DA, USA, 1940.

6. Happ, S.C. Sedimentation in South Carolina Piedmont Valleys. Am. J. Sci. 1945, 243, 113. [CrossRef]

7. Trimble, S.W. Man-Induced Soil Erosion on the Southern Piedmont, 1700-1970; Soil and Water Conservation Society of America: Ankeny, IA, USA, 1974.

8. Knox, J.C. Historical Valley Floor Sedimentation in the Upper Mississippi Valley. Ann. Assoc. Am. Geogr. 1987, 77, 224-244. [CrossRef]

9. Orbock Miller, S.M.; Ritter, D.F.; Kochel, R.C.; Miller, J.R. Fluvial Responses to Land-Use Changes and Climatic Variations within the Drury Creek Watershed, Southern Illinois. Geomorphology 1993, 6, 309-329. [CrossRef]

10. Beach, T. The Fate of Eroded Soil: Sediment Sinks and Sediment Budgets of Agrarian Landscapes in Southern Minnesota, 1851-1988. Ann. Assoc. Am. Geogr. 1994, 84, 5-28. [CrossRef]

11. Leigh, D.S.; Webb, P.A. Holocene Erosion, Sedimentation, and Stratigraphy at Raven Fork, Southern Blue Ridge Mountains, USA Mt. Rivers Part Watershed Scale Process. Channel Morphol. 2006, 78, 161-177. [CrossRef]

12. Rustomji, P.; Pietsch, T. Alluvial Sedimentation Rates from Southeastern Australia Indicate Post-European Settlement Landscape Recovery. Geomorphology 2007, 90, 73-90. [CrossRef]

13. Leigh, D.S. Morphology and Channel Evolution of Small Streams in the Southern Blue Ridge Mountains of Western North Carolina. Southeast. Geogr. 2010, 50, 397-421. [CrossRef] 
14. Dearman, T.L.; James, L.A. Patterns of Legacy Sediment Deposits in a Small South Carolina Piedmont Catchment, USA. Geomorphology 2019, 343, 1-14. [CrossRef]

15. James, L.A. Legacy Sediment: Definitions and Processes of Episodically Produced Anthropogenic Sediment. Geomorphol. Anthr. Underst. Surficial Leg. Past Present Hum. Act. 2013, 2, 16-26. [CrossRef]

16. Gilbert, G.K. Hydrualic-Mining Debris in the Sierra Nevada; United States Geological Survey: Washington, DC, USA, 1917. [CrossRef]

17. James, L.A. Sustained Storage and Transport of Hydraulic Gold Mining Sediment in the Bear River, California. Ann. Assoc. Am. Geogr. 1989, 79, 570-592. [CrossRef]

18. Miller, J.R.; Lechler, P.J.; Desilets, M. The Role of Geomorphic Processes in the Transport and Fate of Mercury in the Carson River Basin, West-Central Nevada. Environ. Geol. 1998, 33, 249-262. [CrossRef]

19. Lecce, S.A. Spatial Patterns of Historical Overbank Sedimentation and Floodplain Evolution, Blue River, Wisconsin. Geomorphology 1997, 18, 265-277. [CrossRef]

20. Hoyle, J.; Brooks, A.; Brierley, G.; Fryirs, K.; Lander, J. Spatial Variability in the Timing, Nature and Extent of Channel Response to Typical Human Disturbance along the Upper Hunter River, New South Wales, Australia. Earth Surf. Process. Landf. 2008, 33 , 868-889. [CrossRef]

21. Jackson, C.R.; Martin, J.K.; Leigh, D.S.; West, L.T. A Southeastern Piedmont Watershed Sediment Budget: Evidence for a Multi-Millennial Agricultural Legacy. J. Soil Water Conserv. 2005, 60, 298.

22. Bain, D.J.; Green, M.B.; Campbell, J.L.; Chamblee, J.F.; Chaoka, S.; Fraterrigo, J.M.; Kaushal, S.S.; Martin, S.L.; Jordan, T.E.; Parolari, A.J.; et al. Legacy Effects in Material Flux: Structural Catchment Changes Predate Long-Term Studies. BioScience 2012, 62, 575-584. [CrossRef]

23. Grabowski, R.C.; Surian, N.; Gurnell, A.M. Characterizing Geomorphological Change to Support Sustainable River Restoration and Management. WIREs Water 2014, 1, 483-512. [CrossRef]

24. Donovan, M.; Miller, A.; Baker, M.; Gellis, A. Sediment Contributions from Floodplains and Legacy Sediments to Piedmont Streams of Baltimore County, Maryland. Geomorphology 2015, 235, 88-105. [CrossRef]

25. Miller, J.R.; Ferri, K.; Grow, D.; Villarroel, L. Hydrologic, Geomorphic, and Stratigraphic Controls on Suspended Sediment Transport Dynamics, Big Harris Creek Restoration Site, North Carolina, USA. Anthropocene 2019, 25, 100188. [CrossRef]

26. Baillie, M.B.; Salant, N.L.; Schmidt, J.C. Using a Historical Aerial Photograph Analysis to Inform Trout Habitat Restoration Efforts. Earth Surf. Process. Landf. 2011, 36, 1693-1702. [CrossRef]

27. Woelfle-Erskine, C.; Wilcox, A.C.; Moore, J.N. Combining Historical and Process Perspectives to Infer Ranges of Geomorphic Variability and Inform River Restoration in a Wandering Gravel-Bed River. Earth Surf. Process. Landf. 2012, 37, 1302-1312. [CrossRef]

28. Wohl, E.; Lane, S.N.; Wilcox, A.C. The Science and Practice of River Restoration. Water Resour. Res. 2015, 51, 5974-5997. [CrossRef]

29. Bernhardt, E.S.; Sudduth, E.B.; Palmer, M.A.; Allan, J.D.; Meyer, J.L.; Alexander, G.; Follastad-Shah, J.; Hassett, B.; Jenkinson, R.; Lave, R.; et al. Restoring Rivers One Reach at a Time: Results from a Survey of U.S. River Restoration Practitioners. Restor. Ecol. 2007, 15, 482-493. [CrossRef]

30. Wohl, E.; Angermeier, P.L.; Bledsoe, B.; Kondolf, G.M.; MacDonnell, L.; Merritt, D.M.; Palmer, M.A.; Poff, N.L.; Tarboton, D. River Restoration. Water Resour. Res. 2005, 41. [CrossRef]

31. Pander, J.; Geist, J. Ecological Indicators for Stream Restoration Success. Ecol. Indic. 2013, 30, 106-118. [CrossRef]

32. Downs, P.W.; Singer, M.S.; Orr, B.K.; Diggory, Z.E.; Church, T.C. Restoring Ecological Integrity in Highly Regulated Rivers: The Role of Baseline Data and Analytical References. Environ. Manage. 2011, 48, 847-864. [CrossRef] [PubMed]

33. Rhoads, B.L.; Wilson, D.; Urban, M.; Herricks, E.E. Interaction Between Scientists and Nonscientists in Community-Based Watershed Management: Emergence of the Concept of Stream Naturalization. Environ. Manag. 1999, 24, 297-308. [CrossRef]

34. Palmer, M.A.; Bernhardt, E.S.; Allan, J.D.; Lake, P.S.; Alexander, G.; Brooks, S.; Carr, J.; Clayton, S.; Dahm, C.N.; Follstad Shah, J.; et al. Standards for Ecologically Successful River Restoration. J. Appl. Ecol. 2005, 42, 208-217. [CrossRef]

35. Palmer, M.A.; Bernhardt, E.S.; Schlesinger, W.H.; Eshleman, K.N.; Foufoula-Georgiou, E.; Hendryx, M.S.; Lemly, A.D.; Likens, G.E.; Loucks, O.L.; Power, M.E.; et al. Mountaintop Mining Consequences. Science 2010, 327, 148. [CrossRef]

36. Palmer, M.A.; Menninger, H.L.; Bernhardt, E. River Restoration, Habitat Heterogeneity and Biodiversity: A Failure of Theory or Practice? Freshw. Biol. 2010, 55, 205-222. [CrossRef]

37. Kottlowski, F.E. Measuring Stratigraphic Sections; Geological Field Techniques Series; Holt, Rinehart and Winston: New York, NY, USA, 1965.

38. Bridge, J.S. Rivers and Floodplains: Forms, Processes, and Sedimentary Record; Blackwell: Malden, MA, USA, 2003.

39. SSDS. Soil Survey Manual; U.S Government Printing Office: Washington, DC, USA, 1984.

40. Hupp, C.R.; Dufour, S.; Bornette, G. Vegetation as a tool in the interpretation of fluvial geomorphic processes and landforms. In Tools in Fluvial Geomorphology; John Wiley \& Sons, Ltd.: Hoboken, NJ, USA, 2016; pp. 210-234. ISBN 9781118648551.

41. Spangenberg, A.G. Journal of August Gottlieb Spangenberg's Voyage to North Carolina to Establish a Moravian Settlement, 13 September 1752-8 January 1753; 1752. Volume 5. Available online: https://docsouth.unc.edu/csr/index.php/document/csr050001 (accessed on 10 October 2021).

42. Link, W.A. North Carolina: Change and Tradition in a Southern State; Harlan Davidson: Wheeling, IL, USA, 2009.

43. CCSWCD. CCSWCD Cleveland County Agriculture; Cleveland Soil and Water Conservation District; Arcadia Publishing: Charleston, South Carolina, 2016. 
44. Rosgen, D.L. A Classification of Natural Rivers. Catena 1994, 22, 169-199. [CrossRef]

45. Rosgen, D.L. Watershed Assessment of River Stability and Sediment Supply (WARSSS); Wildlands Hydrology: Fort Collins, CO, USA, 2006.

46. Kondolf, G.M.; Larson, M. Historical Channel Analysis and Its Application to Riparian and Aquatic Habitat Restoration. Aquat. Conserv. Mar. Freshw. Ecosyst. 1995, 5, 109-126. [CrossRef]

47. Miller, J.R.; Ritter, J.B. An Examination of the Rosgen Classificaton of Natural Rivers. Catena 1996, 295-299. [CrossRef]

48. Simon, A.; Doyle, M.; Kondolf, M.; Shields, F.D., Jr.; Rhoads, B.; McPhillips, M. Critical Evaluation of How the Rosgen Classification and Associated "Natural Channel Design" Methods Fail to Integrate and Quantify Fluvial Processes and Channel Response1. J. Am. Water Resour. Assoc. 2007, 43, 1117-1131. [CrossRef]

49. Kondolf, G.M.; Piégay, H.; Schmitt, L.; Montgomery, D.R. Geomorphic classification of rivers and streams. In Tools in Fluvial Geomorphology; John Wiley \& Sons, Ltd.: Hoboken, NJ, USA, 2016; pp. 133-158. ISBN 9781118648551.

50. García, J.H.; Ollero, A.; Ibisate, A.; Fuller, I.C.; Death, R.G.; Piégay, H. Reply to Comment on “Promoting Fluvial Geomorphology to 'Live with Rivers' in the Anthropocene Era" (García et al., 2021) by D. Rosgen (2021). Geomorphology 2021, 107837. [CrossRef]

51. García, J.H.; Ollero, A.; Ibisate, A.; Fuller, I.C.; Death, R.G.; Piégay, H. Promoting Fluvial Geomorphology to "Live with Rivers" in the Anthropocene Era. Geomorphology 2021, 380, 107649. [CrossRef]

52. Lave, R.; Doyle, M. Streams of Revenue: The Restoration Economy and the Ecosystems It Creates; The MIT Press: Cambridge, MA, USA, 2021; ISBN 9780262539197.

53. Fryirs, K.; Brierley, G.J.; Erskine, W.D. Use of Ergodic Reasoning to Reconstruct the Historical Range of Variability and Evolutionary Trajectory of Rivers. Earth Surf. Process. Landf. 2012, 37, 763-773. [CrossRef]

54. Schumm, S.A. River Metamorphosis. J. Hydraul. 1969, 95, 255-274.

55. Schumm, S.A.; Harvey, M.D.; Watson, C.C. Incised Channels: Morphology, Dynamics, and Control; Water Resources Publications: Littleton, CO, USA, 1984.

56. Watson, C.C.; Biedenharn, D.S.; Bledsoe, B.P. Use of Incised Channel Evolution Models in Understanding Rehabilitation Alternatives. J. Am. Water Resour. Assoc. 1986, 38, 151-160. [CrossRef]

57. Simon, A.; Hupp, C.R. Channel Evolution in Modified Tennessee Channels. In Proceedings of the fourth Federal Interagency Sedimentation Conference, Las Vegas, NA, USA, 24-27 March 1986; pp. 5.71-5.82.

58. Simon, A. Gadation Processes and Channel Evolution in Modified W TN Streams; U.S. Geological Survey Professional Paper; US Government Printing Office: Washington, DC, USA, 1994.

59. Booth, D.B.; Fischenich, C.J. A Channel Evolution Model to Guide Sustainable Urban Stream Restoration. Area 2015, 47, 408-421 [CrossRef]

60. Rosgen, D.L. Applied River Morphology; Wildlands Hydrology Books: Pagosa Springs, CO, USA, 1996.

61. Brunsden, D.; Thornes, J.B. Landscape Sensitivity and Change. Trans. Inst. Br. Geogr. 1979, 4, 463-484. [CrossRef]

62. Brierley, G.; Fryirs, K. Don't Fight the Site: Three Geomorphic Considerations in Catchment-Scale River Rehabilitation Planning. Environ. Manag. 2009, 43, 1201-1218. [CrossRef]

63. Schumm, S.A. Geomorphic thresholds and complex response of drainage systems. In Fluvial Geomorphology; Morisawa, M., Ed.; Publications in Geomorphology; State University of New York: Binghamton, NY, USA, 1973; pp. $299-310$.

64. Phillips, J.D. Changes, Perturbations, and Responses in Geomorphic Systems. Prog. Phys. Geogr. Earth Environ. 2009, 33, 17-30. [CrossRef]

65. Verstraeten, G.; Broothaerts, N.; Van Loo, M.; Notebaert, B.; D’Haen, K.; Dusar, B.; De Brue, H. Variability in Fluvial Geomorphic Response to Anthropogenic Disturbance. Anthropog. Sediment. 2017, 294, 20-39. [CrossRef]

66. Miller, J.R.; Lord, M.L.; Germanoski, D. Meadow sensitivity to natural and anthropogenic disturbance, Chapter 5. In Geomorphology, Hydrology, and Ecology of Great Basin Meadow Complexes- Implications for Management and Restoration; Chambers, J.C., Miller, J.R., Eds.; General Tecnical Report; U.S. Department of Agriculture, Forest Service, Rocky Mountain Research Station: Fort Collins, CO, USA, 2011.

67. Chambers, J.C.; Miller, J.R.; Lord, M. A Field Guide for Evaluating Resilience to Disturbance and Ecological Integrity of Great Basin Riparian Ecosystems: A Rapid Assessment Protocol; General Techical Report; USDA, Forest Service, Rocky Mountain Research Institute: Fort Collins, CO, USA, 2021.

68. Miller, J.R.; Craig Kochel, R. Use and Performance of In-Stream Structures for River Restoration: A Case Study from North Carolina. Environ. Earth Sci. 2008, 68, 1563-1574. [CrossRef]

69. Miller, J.R.; Craig Kochel, R. Assessment of Channel Dynamics, in-Stream Structures and Post-Project Channel Adjustments in North Carolina and Its Implications to Effective Stream Restoration. Environ. Earth Sci. 2010, 59, 1681-1692. [CrossRef]

70. Rosgen, D.L. A Practical Method of Computing Streambank Erosion Rate. In Proceedings of the 7th Federal Interagency Sedimentation Conference, Reno, NV, USA, 25 March 2001; Volume 2, pp. 9-15.

71. Macfall, J.; Robinette, P.; Welch, D. Factors Influencing Bank Geomorphology and Erosion of the Haw River, a High Order River in North Carolina, since European Settlement. PLoS One 2014, 9, e110170. [CrossRef] [PubMed]

72. Simon, A.; Pollen-Bankhead, N.; Thomas, R.E. Development and Application of a Deterministic Bank Stability and Toe Erosion Model for Stream Restoration. In Stream Restoration in Dynamic Fluvial Systems; American Geophysical Union (AGU): Washington, DC, USA, 2011; pp. 453-474. ISBN 9781118666678. 
73. Dunne, K.B.J. A Sticky Pursuit of the Threshold Channel: The Effect of Cohesion on Alluvial River Channel Geometry; University of Pennsylvania: Philadelphia, PA, USA, 2019.

74. Booth, E.G.; Loheide, S.P., II. Effects of Evapotranspiration Partitioning, Plant Water Stress Response and Topsoil Removal on the Soil Moisture Regime of a Floodplain Wetland: Implications for Restoration. Hydrol. Process. 2010, 24, 2934-2946. [CrossRef]

75. Booth, E.G.; Loheide, S.P., II. Hydroecological Model Predictions Indicate Wetter and More Diverse Soil Water Regimes and Vegetation Types Following Floodplain Restoration. J. Geophys. Res. Biogeosci. 2012, 117. [CrossRef]

76. Leopold, L.B.; Wolman, M.G.; Miller, J.P. Fluvial Processes in Geomorphology; W.H. Freeman: San Francisco, CA, USA, 1964. 